
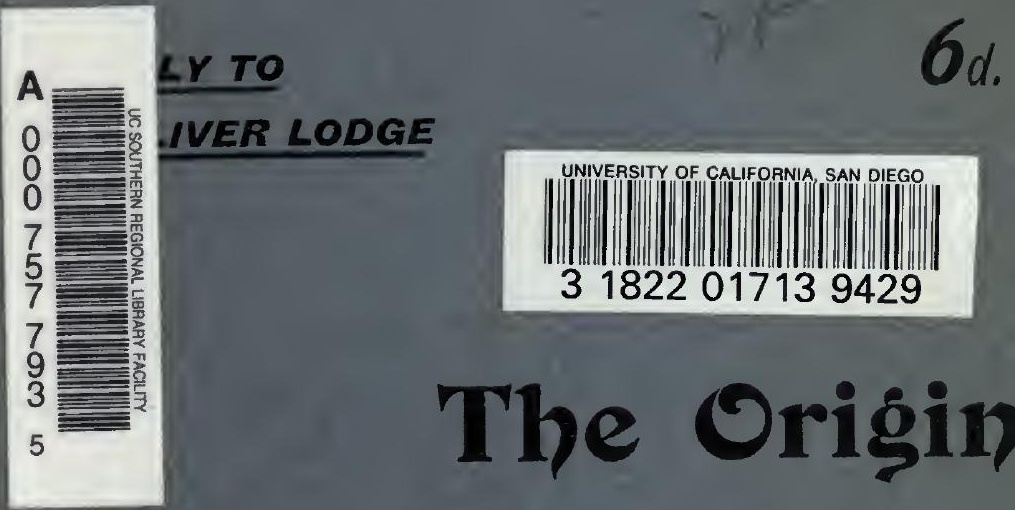

ornia

lal
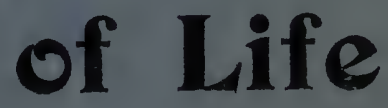

BY

JOSEPH McCABE

(AUTHOR OF "HAECKEL'S

CRITICS ANSWERED")

\author{
LONDON : \\ WATTS \& CO,
}

17, JOHNSON'S COURT, FLEET STREET, E.C. 


\section{Central University Library}

\section{University of California, San Diego}

Please Note: This item is subject to recall.

\section{Date Due}

\section{MAR 081994 \\ MAR 171994}




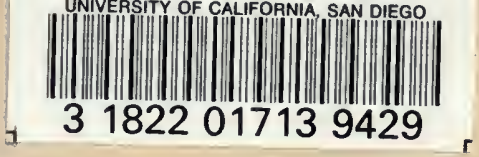

\section{THE ORIGIN OF LIFE}





\title{
THE ORIGIN OF LIFE
}

\section{A REPLY TO SIR OLIVER LODGE}

\author{
JOSEPH ${ }^{\beta Y} \mathrm{McCABE}$ \\ (Author of "Haeckel's Critics Answered," etc.)
}

[ISSUED FOR THE RATIONALIST PRESS ASSOCIATION, LIMITED]

WATTS \& CO.,

17, JOHNSON'S COURT, FLEET STREET, LONDON, E.C.

1906 


\section{Digitized by the Internet Archive in 2007 with funding from Microsoft Corporation}




\section{CONTENTS}

Preface

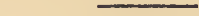

CHAPTER I.

The Nature of the Problem -
Chapter II.

The Simplest Forms of Life $\quad \cdot \quad$ - $\quad$ - $\quad$ - $\quad 29$

CHAPTER III.

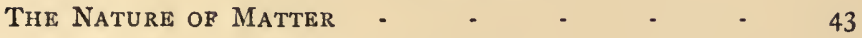

CHAPTER IV.

IN THE BeginNing - $\quad$ - $\quad$ - $\quad$ - $\quad$ - $\quad$ - 59

CHAPTER V.

The Evolution of Life and Mind 



\section{PREFACE}

A LiTTLE work that has been recently issued by Sir Oliver Lodge, one of the most gifted physicists in this country, affords an instructive commentary on the opinion that the conflict between science and theology is over. The thoughtful reader cannot but see that such an opinion is a very superficial estimate of the relation of these two great branches of thought. That theologians contrive to persuade themselves of so desirable a consummation is not a matter of surprise; nor can we wonder that even Agnostic men of science, eager to save their valuable special research from the hampering complication of this conflict, frequently express, though on very different grounds, a somewhat similar opinion.

The discerning observer who stands outside both camps cannot fail to see that the truce is a hollow one. If the fundamental doctrines of theology are to be held in any other than a figurative sense, they demand for their base a spiritual universe that is not an evolution or an outcome of visible nature. If the principle of life and thought in man can be conceived as an especially elaborate synthesis of the 
energies or movements associated with the basic forms of matter, the belief in its immortality, already attenuated into a wistful hope, thins away into nothingness. Since the expert of either physical or biological science has, as such, no concern with the nature of the human mind, there is some apparent reason in his petulant insistence that he cannot come into conflict with any rational scheme of theology. But the ground is only apparent. And the attempt of Sir Oliver Lodge to spiritualise the principle of life, an attempt that has brought him into sharp conflict with our biologists, puts the situation in an admirably clear light.

For some such demonstration as that essayed by Sir Oliver Lodge is absolutely necessary if the distinct spiritual world, on which theology builds in its teaching as regards man, is to be maintained. It was thought by the late Professor Mivart and by Dr. A. Russel Wallace that a stand might be made against what is called "Materialism" at the frontier of human history. The "whole cosmological domain" might be yielded to the exactions of Tyndall, provided we could mark off the human soul as something essentially distinct from it and not involved in its ceaseless dissolutions. Unfortunately for this position, the light that has now been thrown on prehistoric man entirely prevents us from accepting it. We shall see presently that the 
evidence for the evolution of man's soul from that of a lower animal is as cogent as that for the evolution of his body. The mind of man differs only in degree from the mind of the lower animal: it is the same vital principle in a higher phase of development. The spiritualist is, therefore, compelled to claim that all life is immaterial in its nature. The vital principle that first unfolds its powers in the tiniest and simplest living things, and advances by a continuous evolution up to its most splendid manifestation in the brain of man, is distinct at the very root from the familiar agencies in nature. It belongs to a different world of being, and merely manifests itself through material frames, for some inscrutable reason, when the proper conditions are given. It is a kind of spiritual reservoir, existing apart from the cosmic fund of material energies. Little bits detach themselves from the "big lump" (in Sir Oliver Lodge's words) and animate material bodies. When the frames decay they go back into the immaterial world.

This is the theory now advanced by Sir Oliver Lodge as a basis on which theology may be rationally reconstructed. The fact that his large scientific attainments lie entirely outside the domain of biology (the science of life), and that his views have met with a very hostile reception on the part of the biologists of this country, must indeed induce us to examine his theory in the critical mood in which, for instance, 
we scrutinise Professor Haeckel's excursions into ecclesiastical history, but should influence us no further. The speculations of a trained thinker and widely informed student are always entitled to respect. I propose, therefore, in the following essay to give in readable form the actual condition of our knowledge of the origin and nature of life, and to see how far Sir Oliver Lodge's theory is consistent with it.

The task is rendered somewhat difficult from a variety of reasons that the reader will appreciate as we proceed. The theory is put forward in language which is neither clear nor consistent. It is throughout stated as the alternative to a "Materialistic" conception of life which exists mainly in Sir Oliver Lodge's imagination and a few dusty and forgotten controversial works. It is contrasted all through Sir Oliver's work, Life and Matter, with the theory of Professor Haeckel; but this is quite erroneously stated and most unfairly misrepresented. When, in addition, the reader finds Haeckel's system assailed with a shower of such painfully familiar missiles as "miserable and degraded Monism," " extravagant pretensions," "free-and-easy dogmatism," "rather fly-blown production," "jubilant but uninstructed and comparatively ignorant amateur materialist," and when he remembers that these come from the Principal of an English University and one of the most religious thinkers of our time, he feels a sort of compulsion to accept what is set 
forth as the alternative. And, finally, there is the difficulty that all the considerations advanced by Sir Oliver Lodge are little more than false buttresses of his system. All the tantalising analogies that we are begged on every page "not to press too far," all the imposing technicalities of physics that the average reader must take on trust to have some important bearing on the nature of life-all these things do but distract attention from the real ground of Sir Oliver Lodge's theory of life. That real ground is found in the spiritist interpretation of uncommon psychic phenomena. I suggested this in the Hibbert Journal for July, I905. Among others Professor Hyslop, of Columbia University, wrote me : "It has always struck me that Sir Oliver Lodge had come to his conclusion about a theistic view of things from one set of facts, and tried to prove it by another set which in fact do not prove it." Mr. Mallock and other writers have made the same point.

In view of these difficulties I propose to rely mainly on a constructive presentment of the facts bearing on the nature of life. We may, as we proceed, deal with the chief fallacies in Sir Oliyer Lodge's elusive speculation, in so far as he gives them expression.

$$
\text { J. M. }
$$

London, December, roo5. 



\section{ChAPTER I.}

\section{THE NATURE OF THE PROBLEM}

Some time in the remote past, in the remote corner of space that our solar system then occupied, a huge fragment was torn from the glowing central mass and began to press and squeeze into the form of our planet. How it was detached from the contracting fiery cloud, whether as a ring at the surface or a projected mass, we cannot say with confidence. When it was detached is equally a matter of conjecture. We can only say that the limitations which Lord Kelvin so long imposed on geological estimates have been discredited by the discovery of radio-activity, and the vista of the past stretches out endlessly before the calculating mind. The present President of the British Association invites us to think of it in terms of 1,000 or even 2,000 million years. Those are problems of the future. It is germane to my inquiry merely to state that at some inconceivably remote epoch our planet was a fiery offspring of the sun, a formless chaotic mass, millions of miles in diameter. When we remember that the sun is now $15^{\circ}$ times as luminous as the incandescent lime in the optic lantern, and has a temperature expressed in several thousands of degrees, we realise that the little sun our earth then was had no living things upon or within it. 
Then came the normal sinking of the heavier elements to the centre; the flinging out of the red-hot gases to the circumference; the tentative encrusting of the central molten mass, broken by the ceaseless volcanic spurts of liquid fire, until the monster's energy was partly spent. Then was formed the continuous solid crust, thinly encasing the molten globe. Thicker and thicker it grew, as the heat poured out into space. The combination of oxygen and hydrogen gas, which we have learned to call water, condensed in the cooling atmosphere, as it does in the cloud to-day, and fell on the crust. How long it fell only to be shot back in hissing rushes of steam; how long it foamed and tossed, a boiling flood, on the heated surface, we cannot say. The time came when a warm and placid ocean clothed the whole surface of the globe. Probably from the first the solid crust of the earth was uneven. Certainly at a very early geological age comparatively small continents were lifted above the water. But over the broad earth the distant astronomer would have seen little but the steaming mass of water. And somewhere in the depths or the shallows-it is not clear which-of this vast primitive ocean the first terrestrial living things appeared. Whence did they come? What were they like? That is the problem of the origin of life.

It is important to remember that the only problem discussed under this title by Professor Haeckel in the work which Sir Oliver Lodge attacks is the problem of the origin of life a hundred or a thousand million years ago; the first appearance of life on our planet. Sir Oliver says (p. 4I) :- 
The experimental facts of biogenesis he discards in favour of a hypothetical and at present undiscovered kind of spontaneous generation.

When we recollect that this is the third formulation-under the severe strictures of Professor Ray-Lankester-of Sir Oliver's opinion, it has a singular complexion. The "facts of biogenesis" have, as Sir W. Turner pointed out long ago in his presidential speech, no bearing on the problem. They are not discarded in the least degree by Haeckel; they are irrelevant. The positive facts merely amount to a proof that certain species of microscopic organisms, which no one to-day would dream of as arising by spontaneous generation-such as the infusoria-are born of living parents. Beyond this we can only say that the great majority of biologists acknowledge no present instance of living things arising by spontaneous generation. I say the great majority because there are biologists of distinction (Dr. Bastian, Professor Naegeli, and others, as well as Professor Haeckel) who believe, partly on experimental grounds, that things are born to-day by spontaneous generation. Moreover, at the very time when Sir Oliver Lodge was penning his dogmatic phrase, the claim of two competent students (Mr. Burke and M. Dubois) to have produced living things without living parentage was under the serious consideration of science, as he knew.

Indeed, it is really quite meaningless to quote "the facts of biogenesis" in connection with the matter, though it impresses the uninformed. Biogenesis means that a living thing is born, by seed, by budding, by spores, or by 
cleavage, from a previous living organism. Now, the first living things cannot possibly, from the force of the terms, have arisen by biogenesis. They must have had no living parent. Sir Oliver Lodge sees this clearly enough at a later stage. He notices (p. 197) the recent attempts to create life in the laboratory :

Suppose it was successful [he says], what then? We should then be reproducing in the laboratory a process that must at some past age have occurred on the earth; for at one time the earth was certainly hot and molten and inorganic, whereas now it swarms with life.

That is to say, Sir Oliver Lodge on one page tells us that a fact of abiogenesis or spontaneous generation would be a repetition of the process by which the life-story began ages ago; and on another page he tries to discredit Professor Haeckel for "discarding the facts of biogenesis" and entertaining the hypothesis of abiogenesis.

Then Sir Oliver endeavours to extricate himself by a remarkable procedure. It is well to remember that Professor Ray-Lankester had already sharply reprimanded him for his inaccuracy on this very point, and I had pointed out his confusion in the Hibbert. Now, in his mature deliverance, he says that he would be "quite content" if it " could be universally recognised that it is expressly as a hypothesis that Haeckel formulates his conjecture as to the manner of the origin of life." These were my words in the Hibbert. Sir Oliver Lodge replies that Haeckel does not formulate it hypothetically, but dogmatically. On the very page where he makes the point (p. 42) he quotes Haeckel 
himself speaking of his "hypothesis of spontaneous generation." He even plays with the word "hypothesis," and says "it can hardly be maintained that a "hypothesis' is able to 'decide' any dispute." I In the very next paragraph he charges Haeckel with failing to state it as a mere hypothesis :-

An unscientific reader could hardly imagine that the apparently detailed account given in the next sentence of the automatic origin of life, as it may have arisen on other planes [planets], and must have arisen on this, is of the nature of hypothesis.

$\mathrm{He}$ immediately subjoins, as sentences taken from the Riddle of the Universe, the following :-

First simple monera are formed by spontaneous generation, and from these arise unicellular protists....... From these unicellular protists arise, in the further course of evolution, first social cell-communities, and subsequently tissue-forming plants and animals (p. I3I).

These sentences surely have a dogmatic ring, and lend serious authority to Sir Oliver Lodge's persistent and wearisome cry of "dogmatism." There are worse things than dogmatism. I open my Riddle of the Universe at the page quoted (I3I). To my amazement I find that they are taken from a purely hypothetical account, in a series of theses, of the probable course of life-development on other planets. Every single sentence begins with, "It is very probable that," or "It is very questionable whether." Sir Oliver Lodge has struck out the words, "It is very probable

"Haeckel, of course, said nothing of the kind. He said the hypothesis was important to us "in deciding" the dispute. 
that," and then assured his readers that one would "hardly imagine" the theses were hypothetical. He may say that the words are conjectural as regards other planets, but dogmatic as regards our own. But where Haeckel deals with the genesis of life on earth he repeats over and over again that it is a "hypothesis," and the excision of the words, "It is very probable," must be seriously misleading.

From this perplexing polemic let us return to the constructive problem. The "facts of biogenesis," such as they are, shed no light on the primeval origin of life. As Sir Oliver Lodge himself holds (p. 197) that even a proved fact of abiogenesis (as in Mr. Burke's experiments) would not support Haeckel's theory, it seems a pity he referred at all to the question of actual biogenesis or abiogenesis. His own hypothesis of the origin of life is wholly independent of such experiments : so, on his reasoning, is the hypothesis of Professor Haeckel. The question is : Whence came the tiny living things that made their appearance in the primeval ocean? Did they come, in the form of germs, from another planet? Were they suddenly brought into existence by a creative fat? Were they formed by the wedding of principles or particles from an immaterial universe with material frames? Did an eternal and distinct vital spirit then introduce itself into an equally eternal but hitherto inanimate matter? Or were these living things a natural evolution of the matter and energy we are familiar with? 
It cannot be said that biology has formulated any answer to these questions. Indeed, it is ridiculous to suppose that any biologist or paleontologist could use any other than purely conjectural language in attempting to describe the origin of life. The reason is a very simple one. We have no direct knowledge whatever of the first life-forms, or of the species that were evolved from them for millions of years. They had no hard parts that could be preserved in the mud that would one day form our rocks. They were bits of a soft gelatinous matter that melted away as soon as the lifeenergy ceased to hold it together. IVe can only conjecture what they were like from the analogy of the lower living organisms, and from the earlier phases of embryonic development. But we do not suppose-we have no reason for supposing - that even the most primitive organisms now living, even the simplest phase of the individual-germ in the ovary of an infant, tells us what the first living things were like. They may have been far simpler than anything now known to us in the world of life. If the principle of evolution held good in their origin, they must have been. In any case, the question what they were like is one for the constructive imagination, for informed conjecture. Even if the evolutionist omits to say, "It is probable that," at every step in his construction, the conditions of the problem, the complete blank in the earlier chapters of the story of life, are now so generally known that no one is likely to be misled.

In view of this lack of positive data, most of our biologists hesitate to pen their speculations on the subject at all. 
They pursue the prevailing and very useful ideal of "exact" science. They accumulate facts with which some later and larger mind may build, or with which they themselves may build when they think the material complete. This is the only difference between Professor Haeckel and most of his great biological colleagues on the subject of the origin of life. They think that a hypothesis framed in the present state of our knowledge is bound to be insecure. If, indeed, Haeckel advanced his speculation as the positive teaching of biology, they would differ from him. No biologist in this country has done so; and I have shown that Sir Oliver Lodge's charge of doginatism has a basis which we must at once repudiate. On the other hand, few, if any, biologists would dispute that Haeckel is, from the scientific point of view, one of the best-equipped in the world for such speculations. This is an estimate of his qualifications by one of the first biologists in England (in a recent letter to me) :-

Haeckel is one of the first living biologists. There are not any others who have the same wide knowledge and experience, and consequent "point of view." He knows his zoology, botany, physiology, and pathology, also geology, and has travelled, and has a keen interest in and knowledge of no small degree of philology, archæology, and ethnography.

It would be difficult to conceive a higher technical equipment for speculating on the origin and nature of life. I do not wish to press the contrast to the purely physical attainments of Sir Oliver Lodge, but he compels me to protest that Haeckel is something more than " a learned biologist who introduced Darwinism into Germany." Curiously 
enough, Haeckel approached the subject, in 1857 , with a strong bias against spontaneous generation. Among the theses he defended on taking his degree was one that stoutly attacked the possibility of abiogenesis. He knew little about it in those days: few scholars did. In the half century since then he has amassed an extraordinary wealth of biological lore. $\mathrm{He}$ has made special research into several large groups of animals (radiolarians, sponges, medusæ, siphonophores, etc.). He has written forty volumes, some of which have been translated into fifteen languages. He holds four of the highest gold medals available for biological research, and some eighty diplomas from universities and learned bodies all the world over. If we are to have speculation at all on the nature of life, here surely is an impressive equipment for it. Since every reader must know that the whole question of the origin of life is conjectural, and since Haeckel repeatedly recalls the fact (when he is read in the original, and not in Sir Oliver Lodge's quotations), we need not wonder that the general public have failed to be impressed by the sectarian carping of his critics on this point.

But is it worth while to frame these hypotheses at all? Should we not forego the luxury of speculations that are in advance of, even though they are firmly grounded on, the actual evidence? One might reply that, provided we remember always that they are speculations, there is no reason whatever why we should renounce the interest of theories that are sketched for us by competent students of biology. But, in truth, a matter of much more serious 
import is involved. Speculation on the origin of life is vitally connected with speculation on the nature of life; and this in turn is most intimately bound up with a large and important religious controversy. If Lodge is right and Haeckel wrong, the theologian has found a magnificent ground in the real world for the reconstruction of his theory of man. In this aspect the question is assuredly of the first importance. We must speculate. We must examine carefully the whole available evidence, and see whether it lends any colour to this remarkable theory of Sir Oliver Lodge's, that life is an eternal, self-existing principle, and that our individual life-principles (or souls) persist when the body decays. In this respect the problem of the origin of life is invested with an importance that must overrule the reluctance of the specialist. Haeckel's positive speculations on the actual mode of the origin of life are much simpler than one would gather from Sir Oliver Lodge's high talk about "extravagant pretensions." They are also expressly provisional and temporary. It is Sir Oliver's dogmatic negation that calls for the closest attention. He denies that life was evolved from inorganic energy, because it is not inorganic energy or any synthesis or development of inorganic energies. This would be a discovery of tremendous and far-reaching importance, and we must see whether it is justified by the facts of biological science, or whether it is not an aërial structure framed in ignorance of a large and essential part of them.

Thus we get a definition of our problem in terms that 
give it more than a mere scientific interest. We take our primitive living things, making their appearance in the primordial ocean, and ask: Were these simple organisms built up entirely out of elements already existing in our planet? Or are we compelled to think that a third persistent factor (besides matter and energy) now came upon the scene of nature from the obscure recesses of a spiritworld?

In approaching such a problem as this we have first to remember two great and established laws. One is a law of things; the other a law of thought. One is established by science, and is claimed to be one of its very broadest inductions ; the other is established by logicians, and is claimed to be one of the essential conditions of all thinking that seeks to attain the truth. The first is the law of evolution; the second the law of parsimony.

We have to explain the origin of a number of things, living organisms, that make their appearance for the first time on our planet. How do we usually approach such problems to-day? In the old days people were quite accustomed to imagine things shooting suddenly into existence without any natural preparation. Not only religion and morality, but agriculture, the use of metals, speech, and a hundred other human possessions, were believed to have been suddenly thrust into our sphere from a sphere beyond. People had lost all account of their slow and laborious development, and attributed them to a beneficent revelation from the gods. We have altered all that. We have grown instinctively to look for gradual development, and greatly to 
distrust theories of sudden appearance. No ethnographer now admits any other origin but evolution for religion, morality, social organisation, industry, agriculture, clothing, language, art, science, or letters. In some cases, such as language, we have little or no analogy to guide us, because every savage tribe has articulate speech; yet we do not doubt the fact of the evolution of language, because it is not clearly beyond the range of evolution. Thus we look round on the whole rich inheritance of modern civilised man, and say that every part of it was evolved. It seems very far, indeed, from the life of the brute, but we know that only the untrained imagination finds any difficulty in that. The historical period is so short in comparison with the whole life of humanity (which some experts put at 700,000 years, and very few put at less than 100,000 years) that a thousand rudimentary stages may have preceded.

It is the same with the origin of man himself. For a long time the old theory of a sudden appearance was stubbornly maintained. To-day every anthropologist of distinction in the world holds the evolution of man, and Church leaders (such as the Bishop of London and the Dean of Westminster) urge their laity to resist no longer. A few experts still raise difficulties about the evolution of man's mind from that of the lower animals. We shall see that the science of prehistoric man has swept these away. Sir Oliver Lodge says "it is probably true that our life and that of the animals are branches of one fundamental vitality." In any case, the one great difficulty alleged is that man's mind could not have been evolved from that of a lower 
animal. The law of evolution is respected as a law. Whatever could be evolved was evolved. Most theologians to-day take that as "a law of the Divine action." For all the other species of animals and the plants evolution is generally accepted. The palm or the elephant is immeasurably removed from the microbe, but we know they were evolved, ultimately, from microbes. Then we take the atmosphere and the solid globe, the glowing sun and its circling planets, and find that all were evolved out of preexisting elements in nature. The astronomer tells us that, when he sweeps the heavens for a thousand billion miles, he finds the same law of evolution everywhere. Now the physicist tells us we have every reason to believe that the elements themselves are a product of evolution. We are rapidly tracing the whole complexity of the universe down to a simple form of matter and a simple form of energy.

Sir Oliver Lodge wants us to admit one exception to this law of evolution, based on this enormous experience of facts. He holds that the principle of life was not evolved; that its first appearance on our planet was due to an invasion from without, just as the Chinaman says of the art of agriculture or of architecture. Certainly, everything cannot have been evolved. At the base of the scheme there must be an agency, or some agencies, that are simple and eternal. It is a fair speculation whether life is one of these. But we must remember that it is reasoning that compels us to say there are ultimate elements which were not evolved. When any particular phenomenon is put before us as such-we do not at present claim the distinction for ether or electricity, 
the simplest things we know-it must be carefully scrutinised. We may be making the same mistake as the Chinaman. The law of evolution runs from end to end of the universe. ${ }^{I}$ From the primitive nebula upward we find the whole contents of our solar system growing into shape. We find the pre-existing elements entering into more and more complex combinations, and so forming objects that seem infinitely removed from them. Midway in this scheme of cosmic development the first living things appear. All before them was evolution. Ever since they have been subject to evolution. Have we not an immense presumption, from analogy, that they, too, were only a re-arrangement of preexisting elements? Shall we not require very rigorous proof from the man who says they cannot have been evolved, and that we must leave our familiar agencies and turn to a mystic, immaterial world for the explanation? We shall see how lightly Sir Oliver Lodge meets this stringent obligation.

The law of parsimony, one of the first laws of thought, compels us to the same attitude. Once more, a law of

I For a few readers it may be necessary to point out that we speak of "law" by analogy. A "law" of science is only a summing-up of the way in which things are done, not a force compelling them to obey. I have not yet met the thoughtful man or woman who has any illusion on the matter, but I see that religious writers are fond of assuring their readers that Rationalists are commonly guilty of this ridiculous confusion. When we talk of an "iron" (as Goethe did) or "inexorable" law of evolution, we mean that our experience of things coming about in this way is so vast and so uniform that exceptions must arouse suspicion. Especially as the loose old habit of imagining things to appear ready-made, like Minerva springing from the brain of Jupiter, still lingers among our neighbours. 
thought is not some sacred and mystic norm that has to be obeyed for transcendental reasons. The logician observes the thought-processes, as the physicist observes natural processes, and draws up a list of the right tracks of reasoning-the paths the mind follows when it reaches true conclusions. One of these "laws," based on a very wide experience, is that "things are not to be multiplied without need." It is not a new discovery. It was well known to the medieval schoolmen, though they paid a masterly inattention to it in practice. All logicians insist on it to-day. You may violate it in your speculations, but you may pay for the violations, as in the case of any other law. If you seek truth, you will observe it ; that is what logicians mean when they use imperious language. How does it apply to our present subject?

There is no discussion to which it is more pertinent. I have said that there must be some or one ultimate and eternal element that was not evolved. It is the ambition of science to reduce the contents of our solar system to two such elements, matter and energy, possibly to one further element in which the two are associated. That would be an ideal Monism, and, as Sir Oliver Lodge says, "all philosophy aims at being monistic" (p. ro). He is, in fact, so sensible of this that he claims to be a Monist. We shall see that he is a Dualist of a very pronounced type. $\mathrm{He}$ says that we have our material frame of things on the one hand, and there is a quite distinct spiritual world or "reservoir" on the other, which reveals itself to us through the living organism. When the cat dies its vital "power" 
returns to the "reservoir," and is not dissolved into inorganic energies. The first living things were, it is true, an arrangement of pre-existing matter and energies, but an arrangement by a different kind of entity altogether, which would one day return to its spirit-world.

That is just where the law of parsimony steps in. You must not multiply things "without necessity." Matter and energy exist, we all know (except a few metaphysicians, who are not sure). You must not add a third irreducible element, life, unless you are quite clear that it cannot be a further developinent of inorganic energy. You must not assume that some mystic "reservoir" of spiritual "power" exists besides visible nature, unless you have very strong proof. You must not say the first living organisms cannot have been evolved, like everything else before and since, unless you can point to very clear characters of the vital "power" that make this impossible. The only "necessity" for multiplying fundamental factors is when you have a phenomenon that demonstratively cannot be reduced to the familiar terms of matter and energy. Our temporary inability to reduce it to those terms is not a reason for regarding it as irreducible.

Sir Oliver Lodge claims that life is a phenomenon of this character. Let us see where he discovers the features of the vital principle that give it this unique position. 


\section{Chapter II. \\ THE SIMPLEST FORMS OF LIFE}

To approach the problem with any confidence we must study an organism at the very lowest grade of the animal scale. I have pointed out that we have no direct evidence whatever of the nature of those primitive beings with whose origin we are concerned. As has often been said, the first chapters of the story of life have been torn out. The first fossil impressions of living things are found in the Cambrian rocks, at the base of the stratified series. They seem to be the relics or imprints of comparatively large sea-weed or of hydrozoa and similar animals. The story of life must have proceeded for ages before these relatively advanced organisms were enclosed in the mud and sand at the floor of the Cambrian and Silurian oceans. Animals and plants at that stage of development are far removed from the bottom of the organic scale to-day. They must have been preceded by a long procession of softer forms that dissolved in the primitive ocean after death, or were burned up or ground up in the rocks as they formed.

We turn, therefore, from the paleontologist to the biologist, from fossil to living types of organisms. Here we at once sink far below the level of the hydrozoa and the large multicellular algæ. We find a thousand species of bacteria 
alone at a much lower level of organisation; and nearly a thousand species of yegetal organisms that equally consist of a single cell or something less than a cell. It is the discovery of this vast world of simple microscopic beings that has made spontaneous generation more conceivable. The famous experiments of Pasteur, which uninformed writers still confusedly quote in this connection, related to organisms with a locomotor apparatus and a degree of sensitiveness that lift them to a much higher place in the animal hierarchy. If the first living things to appear on our earth had been infusoria, we might more reasonably entertain Lord Kelvin's idea of the arrival of germs from other planets, or the theological theory of creation; though even then it is not clear how Sir Oliver Lodge's theory would help us. But we have hundreds of species below the level of the infusoria, and we may be quite confident that when we regard these we are nearer to the original inhabitants of our oceans.

Why may we be so confident, when we acknowledge that we have no remains preserved of these primitive organisms? There is no dispute about the point in biology, but it is worth while pointing out the grounds. One reason is in the general law of evolution. Apart from a comparatively small number of degenerate parasites (especially among worm-like creatures), the story of life runs from the simpler forms to the more complex. Since this has been the absolute rule among the preserved specimens, we have a right to suppose it held good before the fossil stage began. Further-though all biologists would not use this argument-all animals and plants now begin their existence in the form of a simple microscopic 
particle of plasm. As the embryonic development roughly reproduces the past history of a species, we take it that the initial stage represents a very early ancestor of all species. In any case, no biologist conceives the first living things to have been more advanced than the lowest organisms we have to-day.

We must, therefore, take one of the simplest of living organisms and carefully examine its life. And here I must emphasise once more, for the sake of the inexpert reader, that no evolutionist supposes the first living things were even so far advanced in organisation as the tiniest and simplest things that now live. No one supposes that one fine day an alga or a bacillus made its appearance suddenly in the primitive ocean. In that event we should indeed have a very difficult problem to face in the origin of life. We assume that a vast number of stages preceded that linked the living particle of plasm to the natural compounds of the inorganic world. It is a matter of assumption, remember, on any hypothesis. The theologian, Sir Oliver Lodge, and all the rest of us have to assume our starting-point. Life began in some form unknown to us, but certainly not in a form more complex than the simpler forms we know. For the moment, I merely want to insist that the early forms may have been even simpler, infinitely simpler. Very much simpler forms would have little stability, like Mr. Burke's radiobes, and would disappear. But some biologists hold that they are being reproduced daily.

Let us take, to begin with, one of the simpler forms of life known to us and analyse its structure and life. You will 
often have noticed a thin green or blueish-green deposit on damp rocks. This consists of millions of minute living things, which may run down to the five-thousandth of an inch in diameter. Others float in our ponds, others in the sea. There are hundreds of species of these tiny beings, and millions of them in a small visible clump of floating matter. They are the lowest forms of life that we know to-day; though, of course, improved microscopes may reveal still simpler forms in time. Little more than half a century ago they themselves were unknown. We may take one of these tiny creatures, magnify it a thousand times, and observe the movements in which its life consists.

This is, surely, the correct way to attack our problem. If the earliest living things were at least not more complex than they, we must certainly choose the lowest of them for study. Sir Oliver Lodge does not follow that method. The lowest form of life he ever mentions is the amœba or an amœboid cell. The lowest organisms are much simpler than this. The amœba has a very characteristic system of locomotion and a fair degree of sensitiveness. It thrusts out parts of its jelly-like substance, and uses them as arms or legs in case of need. It wraps these temporary projections round particles of food, and it pulls itself along by means of them. Further, the amœba seems to perceive that the particles of food are near it when it thrusts out these arms to enclose them; and if a drop of irritant acid is put in its water-bath, the amœba curls up, or literally rolls up, into a tiny ball. It is not conscious, of course, but it is sensitive. Moreover, in its very structure the amœba 
reveals that it is a comparatively advanced organism. In the centre of its round body there is a special and characteristic firmer spot called the "nucleus" or kernel. It is generally believed, on experimental grounds, that this implies a most important growth in (or towards) organisation. The nucleus is believed to have the function of reproducing the species, while the rest of the body promiscuously attends to the wants of the individual. Finally, the amœba is an animal organism, and feeds on organic matter.

The earliest organisms in our primitive ocean cannot have been like the amcba. This first division of labour must have taken a vast period for its accomplishment. The germ-stuff clearly cut off from the rest of the body, and set in the centre for protection, implies a long line of evolution. The locomotive system similarly points to a long development, especially as we have plenty of living things that have not yet evolved so far. The distinct sensitiveness of the amcba has the same story to tell; and our first organisms cannot have been animal, as they would not have organic matter to feed on.

Why does Sir Oliver Lodge make no attempt to tell his readers what the first living things are likely to have been? He says they cannot have been evolved-taking them body and "soul"-from inorganic matter and energy. Are we to say this without making a most careful study of them ? Some light seems to be thrown on his procedure by a note at the conclusion of his second chapter :-

I am using the term "life" in a quite general sense, as is obvious, for if it be limited to certain metabolic processes 
in protoplasm-which is the narrowest of its legitimate meanings-what I have said about its possible existence apart from matter would be absurd. It may be convenient to employ the word "vitality" for this limited sense.

The point of this curious passage will be apparent when the reader learns that the life of the really simplest organisms consists only of "metabolic processes in protoplasm." They feed (passively), grow, and split into two, like an overgrown nebula, or a large drop of oil. Their life has a remarkably mechanical look. So they are to have "vitality" instead of "life"-the former term being the abstract Latin word for the latter-and it is admitted that they have no vital "power" that needed to come from the spiritual reservoir. Sir Oliver Lodge probably did not realise the bearing of this concession. It means, in the first place, that the earliest living things to appear on our planet had no share of his imagined immaterial power. There is no reason why they may not have evolved from the inorganic world, and, if that is so, the analogy of the origin of all other complex things in the universe bids us conceive them as the outcome of spontaneous generation. It means, in the second place, that we can beat him back step by step, as we ascend the animal scale, and defy him to point out any stage where the possible range of evolution fails and we must fall back on an immaterial world. If all living things are "branches of one fundamental vitality," the "souls" of the higher organisms are an evolution of the soul of the lowest, and that is merely a plexus of "metabolic processes in protoplasm."

In order to make this clear we may return to our really 
lowly organism, instead of dallying with amœbæ. Magnify the speck of gray or greenish matter a hundred times, and it breaks up into tiny dots or granules, possibly lying in a common slimy bed. Take one of them, magnify it a thousand times, and its simple frame stands out clearly enough. No nucleus is to be seen. In scores of species the most eager investigators, with the most powerful microscopes, have discovered no differentiation into germ-matter and body-matter, though many claim they have found the beginnings of one. The only definite details you see in the tiny transparent globule are the specks or grains of its plasm, or its food forming into plasm. It has no organs whatever. It is a minute particle of the thick, viscous matter known as plasm or protoplasm. Take a drop of the white of an egg, and divide it-if you can-into a thousand parts, and you will have some notion of this little creature's structure, or lack of one.

Its "life," or "vitality," is proportionately simple. From the surrounding water it absorbs particles of matter, organic or inorganic, assimilable or inassimilable. Put finely ground paint into the water, and it will absorb granules of it. They pass laboriously in and out of the viscid little mass. There is no pursuit of food, no choice of useful and declining of useless matter. It is absurd to seek any mystic entity here. We cannot explain the whole metabolism-as the intake and output of matter is called-because the structure of the plasm is not yet understood. But we do know that the molecular structure is enormously complex, and we shall expect a correspondingly complex play of energy. We find 
this; and we go no further for the explanation, but wait until organic chemistry has given us an adequate conception of plasm.

Our microbe increases in size, as it takes matter unceasingly into its little bulk. The fresh atoms or molecules are built up into the plasm by chemical affinity-Sir Oliver Lodge gives an admirable account of this in his last chapter -and the circumference of the tiny globule swells out from its centre. When a certain size is reached the body slowly changes its shape from round to oval. The old centre seems unable to hold the little mass together. A new centre is formed (an invisible centre of attraction) in each half of the oval. It lengthens slowly, sinks in a little round the thick centre, like a drop of oil or ink that divides into two, grows more and more constricted in the middle. At last the two halves hang together by a thin cord of plasm. They slowly fall away, the last connection disappears, and there are two microbes instead of one. Each begins the life-story da capo.

This is the typical life of the lowest living things. They absorb matter, swell, and fall into two. Must we at once abandon all hope of a natural explanation of such beings, and appeal to an immaterial world? It would surely be a very poor repetition of the old fallacy that saw invisible spirits at work in every storm and every crash of thunder. We have learned by a thousand disillusions that it is a fallacy to discard natural agencies the moment we are faced with phenomena that are in any degree mysterious. Already competent students claim to have made artificially in the 
laboratory little beings that feed and grow and multiply in this way; but I would not press these experiments until they have been more widely confirmed. Sir Oliver Lodge admits that it would be "absurd" to claim a spiritual principle in a plexus of metabolic processes. Why does he coin the new word (in the sense in which he uses it) "vitality"? Is this something mid-way between the material and the immaterial, like the long-discarded fiction of Cudworth's? It is utterly unscientific to claim any other than familiar energies in these tiny microbes. The particle of plasm that makes their body consists of millions of atoms in a very complex and very unstable combination. The physical and chemical and electric energies associated with this intricate molecular structure will be correspondingly characteristic. It is absurd to say that they are inadequate to produce the life of a Chroococcus or a Procytella.

I will deal with this point more fully when we have seen something about the constitution of the atom and the molecule, especially the molecule of protoplasm. For the moment we may assume that Sir Oliver Lodge does not insist on the immaterial character of the vital "power" in these lowest and earliest organisms. We turn, therefore, to our second point. Where does the "necessity" come in for multiplying fundamental cosmic agencies? At what point are we compelled to admit that physical and chemical energies clearly fail to explain "life," and to fall back on the suspicious and nystical resource of an immaterial world? 
Since the earlier chapters of the story of life have been destroyed we have no direct knowledge of the forms that immediately succeeded these simple forms. Many of them, however, have survived to this day, so that we can arrange them in an evolutionary series. IVe have thousands of species of organisms that consist of a single cell, a single particle of plasm. We have others that consist of a number of cells loosely associated-the beginning of the multicellular animal. In a word, we have a fairly gradual series of organisms leading up from the microbe to the shark-like ancestors of man, large fishes with brain and excellent senseorgans, that make their appearance at the close of the Silurian period. From these onward the story of evolution is clear enough. At what point does Sir Oliver Lodge's spirit-world break in?

We may take the amœba, which he seems to present as an instance. It is unfortunate that he baffles the critic so much by the vagueness of his indications. The amœba is a much larger particle of protoplasm. It is particularly important for our purpose, because in it we find all the vital functions in a rudimentary form. It splits into two, like the simpler microbes, for reproduction; but it has the germ-stuff apart in a central nucleus. It absorbs foodparticles into its soft, slimy body at any point; but it may send out projections to wrap round the approaching particle. Touch it with a needle, or put a drop of acid in its bath, and it rolls into a ball. Remove the stimulus, and it thrusts out its projections, and crawls along in search of food. Here we have the fundamental functions of nutrition, 
reproduction, movement, and sensation. Are we to suppose that inorganic forces could effect the life of the chroococcus or the bacillus, but not that of the amœba? Even if we had no intermediate species, it would be a very large demand. We have scores of intermediate beings.

As far as nutrition is concerned, there can be no difficulty. It is a physical and chemical process from first to last. From Sir Oliver Lodge's excellent paragraphs on the chemical nature of plasm (in his last chapter) the difference in growth between the crystalloid and the colloid (jelly-like) substance is intelligible. As for the nucleus of the amœba, we can hardly be asked to see a supernatural action in the concentration of the chromatin or hereditary matter (which has nothing to do with the external world) in the centre of the body, thus leaving the superficial matter to get and digest food. Natural selection would obviously tend to effect this. And-though the question taxes the present resources of the microscopist-we seem to find many stages in the formation of nuclei in organisms below the level of the amœba. In many cases, in fact, the presence of a nucleus is warmly disputed. That is all the evolutionist needs. The faculty of locomotion is equally within the range of natural selection. The tense struggle for existence would soon set in among the myriads of primitive microbes. Study a drop of water or ink growing on a table. See how at certain points it reaches out, as it were, towards a larger grain of matter just beyond its rim. The infinitely subtler composition of plasm would make this 
easier for the microbe. It is no great leap to the formation and selection of the pseudopodia of the amœba; in fact, we find the same projections in much lower organisms that have no nucleus (like the Protamaba and others).

There remains the very important function of sensitiveness in the amœba. It must be clearly understood that there is no question of consciousness, in any degree. We have not the least proof of any such possession, and the structureless character of the organism forbids it. It is quite reckless to ascribe to the amœba perception or voluntary movement that imply the least degree of consciousness. The amœba acts as if it felt certain stimuli. In a mechanical, unconscious way it must feel them. In plain English, it reacts on the application of these stimuli. That is by no means beyond the natural range of a complex inorganic body. A strip of gelatine will show the utmost sensitiveness to moisture on the palm of the hand. The film on the photographic plate may be extraordinarily sensitive. The chemist finds many elements to be extremely sensitive to the presence of others; and it is well known how sensitive many bodies are to the action of light, heat, or electricity. Sensitiveness-irritability, as it is called in plasm-is by no means an immaterial function. In a very elaborate and loose compound like the protoplasm of the amœba or the infusorian, we may well expect to find a high manifestation of it. We need not yet fly in despair to a spirit-world.

And if we cannot say that the vital principle of the amœba or the infusorian is clearly more than a plexus of inorganic 
energies, it becomes difficult to draw the line. When a man is convinced on other grounds that there is a spiritual principle in living things, he can, no doubt, make capital of the temporary gaps in the biological scheme. It is not logical, though it may be impressive. But one would like to hear of the competent biologist who would admit the mechanical nature of thousands of the earliest species of living things, and then postulate a spiritual principle for the rest. Defective as our knowledge is, it makes such a suggestion seem ridiculous. We have so nearly complete an evolutionary scheme that there are few biologists living who doubt that all the actual animals and plants have been developed from the primitive unicellular organisms. The next chief stage is a cluster of cells, each of which lives its own life, and may even detach itself and live like an amœba. One would hardly say that it needed an immaterial principle to bring in the obvious advantage of sticking together. The next chief stage (as in the Pemmatodiscus) is that the cluster - which is hollow, each cell having to be at the surface to get its nourishment-doubles in on itself, like an india-rubber ball. The inner cells then confine themselves to digestion and reproduction; the outer to locomotion and reaction on stimuli. This is well within the range of natural selection. The simple worm-like body is a natural development from this; and we have an illuminating series of forms between that and the fish, the fish and the mammal, the lower mammal and man.

But, before we press the subject any further, it will be well to invade Sir Oliver Lodge's own science, and ask the 
physicist for a clearer knowledge of what matter and energy are. Only when we have done this shall we be in a position to speculate with any wiscdom on what matter and energy can or cannot do. 


\section{Chapter III. \\ THE NATURE OF MATTER}

WE have seen how the progressive improvement of the microscope has tended to simplify the problem of the origin of life. A century ago insects and small worms and crustaceans (like fleas) were counted among the lowest representatives of the animal world, and science itself had only just surrendered a belief in their spontaneous generation. Then the microscope began to reveal whole worlds of living things at a far lower level. Scientists still made the mistake at times of taking provisional determinations for final truths. One of the leading microscopists in Europe fifty years ago, Ehrenberg, wrote a work to show that the infusoria he detected in a drop of stagnant water were "perfect organisms." The dim markings his poor microscope discovered in them were shaped by his imagination into the outlines of complete organs. Other scientists, such as Joly and Pouchet, Pasteur's great adversaries, claimed that the infusoria were rudimentary enough to be born by spontaneous generation. Both extremes were wrong. But the microscope went on to reveal to us the hundreds of species of minute, structureless beings we described in the last chapter, and so brought us within sight of the frontiers of the inorganic world. 
While biology was thus narrowing the issue with regard to the origin of life on its side, chemistry was advancing to meet it from the other side. Let me illustrate the matter by a personal experience. Ten years ago I was the professor of philosophy in a Catholic (monastic) seminary at London, and it fell within my province to deal with this problem. According to the most recent works put at my disposal-works written by learned Jesuits and Dominicans, who still lead a large part of the Catholic world-the solution was very simple. Not only could the scientist not produce living things in the laboratory, but he could not even produce dead organic substances. There are a number of substances formed by living organisms-indigo, alcohol, uric acid, formic acid, lactic acid, etc.-that are not otherwise found in nature. I dutifully taught my clerical pupils, ten years ago, that these organic substances baffled the artificial synthesis of the chemist. The living matter itself was, therefore, immeasurably beyond his reach, and clearly due to an immaterial principle. I know to-day that every one of the organic substances I enumerated was being actually produced in laboratories not many miles away from my college. Such is the irony of the Index Expurgatorius.

But within the last five years an even more important revolution has taken place in the science of inorganic nature. The atom has yielded at last to analysis, and our eighty chemical elements are in a fair way to be dissolved in a homogeneous ocean of electricity or ether. Whether the ether is the long-sought materia prima of the universe or not, we are well within sight of that golden dream of science. 
Unification, the reduction of the complex to the simple, is the scientific ideal. The last advance of physics brings us at a bound much nearer to its realisation.

Ill-informed writers have frequentlyassured worse-informed readers of late that this new analysis of matter has made an end of that precious fiction of the religious controversialist, the Materialist. I will say a few words on Materialism later, but it must be stated once for all that the new conception of matter is most welcome and helpful to the writers who are dubbed (though they disclaim the name) Materialists. No writer of the Naturalist school for many decades has talked of the "solid atom," or built on it in any way. It is true that you will find occasional phrases such as: "A simple elemental atom is really an immortal being." But the quotation is from a religious physicist, Balfour Stewart; and the "Materialist" who quotes it, L. Büchner (Force and Matter), goes on to point out that the atom is not really indivisible, and that "the so-called atoms therefore consist of units of a higher grade, as the molecule does of atoms" (p. 49). So wrote the arch-Materialist twenty years ago. Haeckel, writing ten years later, was not less explicit. "The empirical elements we now know are not really simple, ultimate, and unchangeable forms," and ether is probably the materia prima (Riddle, p. 79).

How it comes about that religious writers have so loudly proclaimed the new discoveries to be fatal to "Materialism," when these discoveries were confidently anticipated by the very men to whom they apply the epithet, I leave it to the reader to conjecture. No doubt Sir Oliver Lodge was 
expected to sustain this contention, and in the first version of his attack on Haeckel (in the Hibbert, January, 1905) he said: "It is singular that even during Haeckel's lifetime the atom shows signs of breaking up into stuff which is not ordinary matter." If he had meant that it was a singular joy for Haeckel to see his amateur physical speculation fulfilled during his lifetime, this would be admirable. Unfortunately, he meant the reverse. It is still more perplexing to find that Sir Oliver wrote these words apropos of Haeckel's insistence on the conservation of matter; whereas he now tells us in his work (p. 29) that "the constancy of fundamental material still holds good, even though the atoms are resolved into electric charges." Nor is his misrepresentation of Haeckel relieved when he describes him as a "Materialistic-Monist, with a limitation of the term 'matter' to the terrestrial chemical elements and their combinations-i.e., to that form of substance to which the human race has grown accustomed-a sense which tends to exclude ethereal [italics mine] and other generalisations and unknown possibilities such as would occur to a philosophic Monist of the widest kind" (p. III). Seeing that Haeckel devotes several pages $(78-8 \mathrm{I})$ to ether, which he regards as the fundamental entity, in the very book which Sir Oliver professes to be criticising, this is strange work.

Let us finish with this sorry story of Sir Oliver Lodge's physical criticisms of Haeckel before we proceed to construct. None but a fool would expect a chapter on physics, written by a biologist several years before the discovery of radium, to be free from error. A Sir Oliver Lodge 
should be able to find many inaccuracies in it. Curiously enough, his criticism of it is only impressive where he quite misrepresents Haeckel. We have seen this as regards the atom and the element. $\mathrm{He}$ is hardly more just with Haeckel's ascription of "souls" to atoms. He speaks of his "grotesque assertion" that atoms are moved by "internal likes and desires." He "refrains from characterising the sentence as a physicist should." The word "desire" is a subtle importation of his own. On the next page (48) he makes Haeckel ascribe "life and mind and consciousness" [italics mine] to the atoms. If that were so, there would be some ground for his disdain. But turn to Haeckel once more. On p. 64 of the Riddle he expressly and vehemently repudiates the theory that the atoms are endowed with consciousness. He has a long passage on the subject, and makes it frequently clear that, when he ascribes "will" and "sensation" to the atoms, it is "unconscious" (he italicises the word) will and sensation. His whole theory of "likes and dislikes" and "passion" in the atom, which Sir Oliver Lodge so contemptuously spurns on the ground ithat it is literal, is a figure of speech taken from Goethe's beautiful Wahlverwandtschaften, as Haeckel himself indicates. To borrow Sir Oliver's convenient phrase: "I refrain from characterising the procedure as a humane critic should."

Finally, there is the only physical theorem in the Riddle with which Sir Oliver Lodge was really called upon to deal. This is "the law of substance"-a combination of the inductive laws of the conservation of matter and the 
conservation of energy. Some of Haeckel's clerical critics have recklessly tried to discredit this in itself, but Sir Oliver Lodge knows better." The laws of the constancy of matter and energy are based on so broad an experience that no physicist will allow doubt to be thrown on them. They are, says the latest writer on physics, Mr. W. C. D. Whetham, "two of the most important generalisations ever reached by physical science." Sir Oliver Lodge himself says-we have just seen-that the recent discoveries leave "the constancy of fundamental matter" intact, and that physicists will not tolerate "any the least departure from the law of the conservation of energy, when all forms of energy are taken into account" (p. I55). What can he find to say in the way of criticism ?

We have seen that his unconscious resources are many and peculiar. $\mathrm{x}$ he has two objections to raise. 'The first is that Haeckel has not been content with the empirical grounds of these laws, but has represented the laws as "almost axiomatic and self-evident." Haeckel nowhere does anything of the kind. He constantly reminds the reader that they are empirical. In fact, he would make little use of them if they were not. On the other hand, take phrases such as the following: "Whatever really and fundamentally exists must, so far as bare existence is concerned, be independent of time......can hardly be thought of as either going out of existence, or as coming into existence,

I It need hardly be said that I am only imputing to him a remarkable negligence and hastiness in studying the distinguished foreign biologist he has set out to attack. 
at any given period." Is it Haeckel who gives this "almost axiomatic and self-evident" form to the law of "the persistence of being"? No, it is Sir Oliver Lodge (p. Ior), with another object in view (the immortality of the soul). It is the same Sir Oliver Lodge who, when Haeckel presses the law of substance, tells us that "there is a certain plausibility in the idea, pure guess or assumption though it be" (p. 34).

Then Sir Oliver Lodge complains that Haeckel draws illegitimate conclusions from his law of substance. $\mathrm{He}$ considers "that they solve the main problem of the universe, and that they suffice to replace the Deity himself." On the first point I will only quote a sentence from Haeckel's work: "Can we affirm to-day that the marvellous progress of modern cosmology has solved this 'problem of substance,' or at least that it has brought us nearer to the solution?...... We grant at once that the innermost character of nature is just as little understood by us as it was by Anaximander and Empedocles 2,400 years ago" (p. 134). On the second point I need only say that Haeckel does not "replace the Deity" at all. In quoting Haeckel's words about "the godless world-system of the modern scientist," Sir Oliver Lodge unfortunately leaves out the brief antecedent sentence, which explains that by atheism he means the denial of "a personal, extra-mundane Deity." If that is a shocking conclusion, many of our theologians even are in a bad case. Does Sir Oliver Lodge repudiate it? "One may reverently say that the Deity is not to be considered apart from the universe, but rather-and I will not say a part of the 
universe either" (Science and Religion, p. 2). Qui potest capere, capiat.

Let us take our primitive microbe and study it from a different point of view. It is a tiny thing, immeasurably below the range of unaided vision. The mature human ovum, about $\frac{1}{12}$ of an inch in diameter, fairly marks the range of visibility to the trained eye. We may take a living thing-say the Procytella primordialis-that may not reach a diameter of the 5,000 th of an inch. Magnified a thousand times, it is not much larger than a pin's head; and it shows no sign of structure or mechanism that might accomplish its lowly vital functions.

But where the microscope ends, the work of the physicist begins. The little particle of plasm, far smaller than the tiniest grain of salt that you can pick out with the naked eye, is a mechanism of baffling intricacy. The configuration of our stellar universe is hardly a more perplexing problem. By a process of reasoning that is as safe as microscopic analysis, we

x The only other criticism I have to make at this point is on Sir Oliver Lodge's cheerful statement (p. 47) that "we find Haeckel ignoring the elementary axiom that action and reaction are equal and opposite-i.e., that internal forces can have no motive power on a body as a whole." This must sound delightfully crushing to the religious reader, though how far he will understand it is another matter. Personally I regard it as a piece of bluff, and was confirmed when I submitted it to a student of physics. Sir Oliver Lodge night as well tell a motor-car that the Newtonian law forbids it to run. However, it seems to refer to his wrong idea that Haeckel endows the atom with a conscious soul. 
break it up into hundreds of thousands of molecules of plasm. The merciless analysis then dissolves each molecule into some hundreds of atoms, that had clung together in a structure which still defies the investigation of the chemist. And the physicist now tells us that each atom is a still more complex system of far smaller points, which he calls electrons. To conceive it in the terms which are at present most accepted, the electron is an apparently permanent straincentre in an ocean of ether. More than a thousand of these strain-centres have aggregated somehow, adjusted their respective motions as planets do round a central sun, and formed a comparatively stable system. Within its limits, of the proportionate size of flies in a theatre, they spin in their complicated orbits. Yet $200,000,000$ of these systems, end to end, would not measure an inch. There are trillions of them in a table-spoon full of water. Some hundreds of these systems, of varying size, have joined together to form a molecule of protoplasm, the smallest particle of living matter that we can take without destroying its nature. And some hundreds of thousands, if not a few million, of these large systems (the molecules) are subtly connected to form the tiny Procytella. It is a structure so intricate as to fill the most powerful mathematician with despair.

We must bear this structure in mind when we say that "ordinary matter" is incapable of discharging vital functions unless it is directed or controlled by some immaterial agency. We are not dealing with "ordinary matter" at all. We are dealing with a substance of the most astounding subtlety and complexity. Nor are the intricacy of structure and the 
number of constituent elements the only features to be noted. One of the most characteristic elements in the substance is carbon, and it also contains a high proportion of water. Each of these has an extraordinary power of linking other atoms or molecules to itself, when they approach, in a loose, labile connection that allows a vast amount of breaking-away and recombining. A particle of plasm is, therefore, a thing of wonderful and indeterminable potentialities. The most advanced chemistry of our time could not attempt to deduce the properties that would result from this unstable and complicated system of millions of atoms.

"Such a grouping is likely to have properties differing not only in degree, but in kind, from the properties of simple substances." The proposition seems to promise a basis for a mechanical conception of life. As a fact, the particle of plasm (our microbe) does show properties that differ very considerably from the properties of ordinary matter, though they seem to differ only in degree from the crystal's properties of growth and reproduction. The analogy with the crystal must not, however, be pressed too far. The crystal and plasm lie on very different tracks of molecular development. The crystal is a comparatively rigid system, growing by the addition or accretion at the fringe of new particles. The colloid substance is unstable, and allows particles to pass in and out of its system of atoms-it feeds by intussusception. Hence, if even in the crystal we have remarkable powers of growth and reproduction and multiplication, we shall certainly not be surprised to find them in a subtler form in a substance like plasm. We may or may not expect to find properties 
differing "in kind," but at all events we shall expect remarkable and unique properties.

It is, perhaps, one of the most curious features of Sir Oliver Lodge's book that it is he who expects properties differing "in kind" to emerge from these complex groupings of atoms. The proposition I quote at the beginning of the last paragraph is his (p. 186). He insists that "fresh qualities altogether are liable to be introduced or to make their appearance at certain stages...... in the building up of a complex mass." I will not go through his arguments from analogy, which are largely unsound; but his conclusion is sound enough. It does not require a profound knowledge of physics or chemistry to see that, as the properties of matter change with its combinations, this wonderful complex that we call plasm will exhibit remarkable and characteristic properties. But every admirer of our distinguished physicist must be puzzled by the sequel. After the fine analysis of protoplasm that leads him to the expectation I have quoted, he turns round, when he finds protoplasm actually exhibiting characteristic movements, and says we must call in an immaterial principle to explain them. He has practically explained the vital functions of the lowest organisms to us in mechanical terms, and then he tells us he thinks it erroneous to say that "the complex aggregate generated the life." When hydrogen and oxygen unite, or chlorine and sodium combine, we admit that "the complex aggregate" generated, or made up by transfer, the properties of the resultant water or salt. When the chemist combines three or four elements to produce the 
higher compounds that are known as organic (as until lately they were only produced by organisms), no one raises the least doubt that the complex aggregate has generated the new qualities or combined the elemental energies into them. But when oxygen, hydrogen, nitrogen, carbon, and sulphur unite in a supremely complex aggregate, and certain very distinctive properties appear, we are told they did not generate the new properties, but some mystic entity came in from another world and guided their movements. And if Mr. Burke's radiobes prove to be genuine abiogenetic living things, Sir Oliver Lodge holds that he has only prepared "a vehicle" for the manifestation of life.

This is a clear departure from scientific reasoning in the interest of a spiritist theory that has been set up on other grounds. I do not say, as Mr. Mallock does, on "unscientific grounds"; but, after all, those other grounds are not indicated in this work, and we must ignore them. The scientific procedure is plain. Seeing that, as Sir Oliver Lodge so finely indicates, we are to expect "fresh properties" in the new aggregate, and seeing that the "fresh properties" really emerge, it is idle to imagine the sudden appearance of a mystic principle. It is not in the least required that we show, step by step, how the linking and fusing of the old properties generated the new. Until some feature in the new properties is pointed out that clearly could not be due to the combination itself-and that will be a Sisyphean task for the man who thinks an aggregate may produce properties different "in kind, not merely in degree," from the old-we are content with our material factors. 
That is, in point of fact, the prevailing attitude among our authorities. I have given elsewhere (Haeckel's Critics Answered, p. 43) a sufficient array of quotations to show this. Not only our leading biologists, Professor RayLankester, Sir J. Burdon-Sanderson, and Sir W. T. Thiselton-Dyer, argue in this way, but two of Sir Oliver Lodge's most distinguished colleagues in physics, Sir A. Rücker and Sir J. Dewar, have insisted on it from the presidential chair of the British Association. Professor Lionel Beale, the only prominent biologist in this country who more or less agrees with Sir Oliver Lodge, bewails repeatedly the "materialism" of all his colleagues. One of our first psychologists, Professor J. IVard, says that "the old theory of a special vital force......has for the most part been abandoned as superfluous." I drew the attention of Sir Oliver Lodge to all these statements in the Hibbert (July, I905). He replies by ignoring all my quotations save one (from America), and representing my summary of them as an eccentric and ignorant opinion of my own (p. I3 I). Nowhere in his work does he even hint to the reader that his opinion has been drastically condemned by the leading biologists of this country; on the other hand, he persistently represents Haeckel as "abandoned by the retreating ranks of his colleagues." That is one way of setting right the "misleading statements" of Professor Haeckel.

However, Sir Oliver Lodge has two things to say for himself at this point. In the first place, when I represent him as holding that the "vital force" needs guidance, he 
courteously says it is "nonsense"; that he nowhere used the phrase "vital force." It is, I believe, literally true that he did not. "Vital force" is a phrase that has suffered so much contempt from both physicists and biologists that it would need the courage of a Haeckel to champion it. But what is the nature of this immaterial something of Sir Oliver's that directs the energies of living things? It is neither matter, nor force, nor energy, nor substance, he says. In a formal statement in his preface he calls it a "power." What is a "power"? He defines it in a footnote on p. 165 . "A force in motion is a power," and, as a former professor of logic, I feel entitled to reverse the definition, and say that " a power is a force in motion." It would appear, then, that when Sir Oliver Lodge does come formally to define his intangible something, he uses a phrase that might have spared the strain on his courtesy had he remembered it.

The second point is more material, and the language of Sir Oliver Lodge even more forcible. Speaking of the inorganic energies that must be associated with the atoms of protoplasm, as they are associated with all atoms, I said that "science always finds these inorganic energies to reappear on the dissolution of life." This sentence Sir Oliver Lodge mercilessly italicises and reserves for his grand attack. It draws from him the only positive argument in his book (apart from consciousness, which I will deal with later) in favour of his theory.

Premising that Haeckel "must surely know better" than 
to endorse this utterance of "his disciple," I he wishes "to oppose the fallacy in the strongest terms." Let me briefly repeat "the fallacy." As, in the current language of physics, energy is associated with all particles of matter (many hold that matter is composed of energy), we must admit that there is a remarkable plexus of inorganic energies in the living protoplasm. Sir Oliver Lodge holds that there is something else, and that this continues to exist after death. Haeckel says (like most of our biologists) that what we call life is only the synthesis of physical and chemical forces in the living matter, and, when the material combination breaks up, this synthesis of energies correspondingly breaks up, and the dissociated inorganic energies appear. The reader will see that this alone is implied in my statement. I was correcting Sir Oliver Lodge's erroneous assertion that Haeckel said the principle of life was "resolved into nothingness." There is not the slightest doubt that Haeckel would endorse my statement.

Sir Oliver opens his attack upon it by converting it into the statement that "a dead body has more inorganic energy than a live one." A more astounding conversion, or perversion, I never met. My plain statement could not mean more, even if it were pressed to the utmost limit, than that the dead body has as much inorganic energy as the live one. And remember the essential distinction between latent and

I To be quite accurate, he says "these utterances." Thus he holds up to the ridicule of his religious readers a series of utterances in which I did absolutely no more than echo the words of Ray-Lankester, Thiselton-Dyer, Ward, Le Conte, and a.dozen other authorities. 
active energy. The latent energy of a keg of powder is real enough to the physicist, though the layman's imagination cannot master it. But I did not even say there was as much energy in the dead body. As well make me say there is as much inorganic energy in the rusting old engine beside the line as in the new engine that flies past it with full steam up. And apart from the question of quantity, which I did not introduce, and which could not be determined, it is a mere truism to say that the inorganic energies of the hydrogen, oxygen, etc., that went to make the protoplasm, reappear in the gases and other decaying elements of the body.

The critic concludes this chapter of his work with strong language about Haeckel's "dogmatism" and "benighted fools and credulous dupes." One may invite him to reconsider a sentence he has written on the preceding page (134). "I say that, whatever life is or is not, it is certainly this : it is a guiding and controlling entity which interacts with our world according to laws that are so partially known that we have to say they are practically unknown." This has a dogmatic ring. And the most curious feature of it-in view of its proximity to the plea for the protection of "the uncultured "-is that there is hardly a prominent biologist in England who would endorse the substance of the statement, in the misleading terms which I have italicised. 


\section{Chapter IV.}

\section{IN THE BEGINNING}

We may now return to our constructive task with more confidence. We have found that the world of life is not separated from the inanimate world by a yawning gulf, that would restrain us from thinking of the evolution of the one from the other. When we push out to the very frontiers of the living world we find tiny creatures whose life is hardly worth calling "life" at all, though it may merit the Latin title, "vitality." It consists merely of "metabolic processes," for which it would be "absurd" to claim an immaterial principle. On the other hand, we have learned that "dead matter" $\mathrm{I}$ is not the helpless and unpromising thing it is often conceived to be. It is marvellously rich in potentiality. When its atomic systems with their charges of energy enter into higher combinations, we may expect "properties different in kind," at all events vastly different, from the properties of the elementary substances. When we learn that in the tiny particle of plasm we have such a combination of a remarkably elaborate type-electrons

I A particularly stupid phrase for inorganic matter, that one meets in religious writers. "Dead" means, not devoid of life, but deprived of life. And the antithesis begs the whole question whether life is or is not an immaterial principle. 
grouped into atoms, millions of atoms grouped into molecule-systems of the utmost complexity, molecules grouped into biogens, and biogens united in the little globule of plasm-we do not feel surprise that certain distinctive properties, that we call vital, make their appearance.

But where did the plasm come from ? Let me first point out that we have not merely put back the problem a step. The empirical law that guides us in explaining the contents of the universe is the law of evolution. We have had so uniform an experience of it that we now say-men theologians say-that everything was evolved that could be evolved. There are a few thinkers, like Sir Oliver Lodge, called Vitalists, who hold, for one reason or other, that life could not have been evolved from inorganic energy. We have found that this objection has no substance whatever as regards our primitive microbes. There is no feature in their life that we can claim to be beyond the range of a subtle synthesis of inorganic energies. Therefore the one objection to evolution in their case disappears, and, on the analogy of the whole of the other contents of the universe, on one of the most powerful and broadest inductions of science, we assume that they were evolved.' Evolution is

I A few readers may cling to the old idea that the earliest organisms were created-a notion left open by Darwin in his Origin of Species, but afterwards entirely rejected by him. The assumption brings in a new factor without the least rational justification, and makes the origin of life for ever unintelligible-because no one can pretend that creation out of nothing is intelligible. It must be borne in mind that Sir Oliver Lodge does not countenance this theory for a moment. He says (p. 106) that its "absurdity" is "extreme." 
the way in which complex things come into existence-art, science, morality, civilisation, suns, animals, plants, or atoms. We need something more than a few paltry analogies to make us think there was an exception in the case of life.

We have, therefore, not put back the problem at all, but have stripped it of all mystic entanglements, and seen that it falls within the ordinary range of science. Not that biology as such has anything to say about the origin of life. A reader must be very muddle-headed who imagines that Haeckel, for instance, pretends to be giving him orthodox biology when he deals with the origin of life. He is-he repeats it incessantly-giving his own speculations, based on a remarkable command of the facts of biology. Whether this impressionable reader is less likely to be "unduly influenced" by the dogmatisms of Sir Oliver Lodge and his clerical friends is another matter. I have little acquaintance with such readers.

Where, then, did our first tiny particles of living plasm come from? Here we are in a province of pure conjecture. The biologist at large declines to indulge in such conjectures at all, though he is apt to resent very rudely the pious layman's suggestion that they must have been created, or must have been put together by some spiritual particle from another world. However, a number of able biologists have given us conjectures as to the probable origin of these living things, and they are not without interest. They frankly offer them to us as conjectures. Haeckel hardly ever refers to his theory of the origin of life without calling 
it a "hypothesis." I When the reader remembers Haeckel's qualifications for dealing with the matter-a close study for forty years of the lowest microscopic forms of life, a large amount of masterly original work on many classes of lower animals (radiolaria, calcispongiæ, medusæ, siphonophoræ, etc.), and a very wide command of botany, zoology, paleontology, embryology, and comparative anatomy-he will probably feel that they are not much hurt by the boomerangs of physicists and theologians. However, Haeckel does not give his hypothesis in any detail in the Riddle. He refers the reader to his History of Creation and his untranslated chief work, the Systematische Phylogenie, neither of which seems to have been referred to by his critic. ${ }^{2}$

A curious effort has been made by a number of students, chiefly physicists (including Lord Kelvin), to meet the problem with a conjecture that life probably came from another planet. It is not clear to-day that this would be

"I have already shown how Sir Oliver Lodge omits the words, "It is very probable that," when he has to represent Haeckel as dogmatic. Again, on p. 22, he makes Haeckel hold that "the following cosmological theorems have been 'amply demonstrated." He subjoins four out of twelve given on p. 5 of the Riddle. When you turn to the Riddle you find that Haeckel expressly says " most of them have been amply demonstrated " - and most of them certainly have.

2 The theses on the origin of life which Haeckel gives on p. I3I of the Riddle, and to which Sir O. Lodge contrives to give a dogmatic look, are taken in substance from the Systematische Phylogenie. There they refer directly to the birth of life on our planet. But if the critic had looked them up, he would have found that they begin with the modest words : "Theoretically we may distinguish something like the following stages in the hypothetical process of the origin of life." Nor is anything like real detail attempted. 
impossible. We may suppose that some small planet or large moon of a planet may have been violently shattered, and fragments, bearing germs of life, shot out into space. Could the germs survive the terrible cold (about-200 $\mathrm{C}$ ) of space? There are, of course, microbes that thrive in icecream and in arctic seas; but the cold of space is a different matter. Intense refrigeration is regarded to-day as one of the best methods of killing germs. However, doubt is raised whether these germs from another world might not survive. Then the fragment would enter our atmosphere at a terrific speed, attracted by the earth. It would be raised to incandescence at its surface (a shooting star) by the friction, and probably shattered. Nevertheless, there are students who think it is not impossible for simple germs to survive the adventurous voyage. But the theory is a fantastic possibility, à la Jules Verne, at the most. It casts the responsibility of explaining life on the biologists of another planet. There is no need whatever to do this.

Another conjecture is that life may be itself a simple and eternal form of energy, like electricity. This has some resemblance to the theory of Sir Oliver Lodge in terms, but it is substantially different in the sequel. It does not in the least lend itself to the notion of the persistence of the higher and more complex life-forms-the immortality of the soul. However, like the preceding, it is merely a desperate attempt to get away indirectly from a problem that it regards as insuperable. Above all, it is entirely excluded by the considerations we have seen. The living particle is not a piece of ordinary matter with a peculiar form of energy 
attached to it. Its frame is an enormously intricate structure of millions of electrons : its "spirit" may very well be the synthesis of the inorganic energies of these electrons.

There is no reason to-day why we should run desperately to other planets or spirit-worlds for the explanation of life. We cannot, of course, give a detailed account of a process that took place a hundred million years ago, and left no trace behind except the finished article. If one were attempted, it would be, in the phrase of the picture dealer, " highly speculative." Still, there does seem ground for a few leading ideas that have a strong provisional interest.

If the first living things were evolved, as we have good logical and scientific ground for thinking, there was no beginning of life at all. It is necessary to put it strongly, in order to break down the conventional idea that a few floating or crawling microbes appeared one fine day in the primitive ocean. If even a simple thing like the Chroococcus had suddenly appeared in this way, we should indeed have a formidable problem to face. We have no right whatever to say that the first living things were like the Chroococcus or the Procytella. We have just as good a right to say that they were a thousand times simpler than either. But are these not the lowest living things in existence to-day? IVe do not even know that. A number of competent biologists hold that they are not. I have described our microbe as consisting of some hundreds of thousands, if not millions, of molecules of plasm. It is now generally thought in biology that these molecules are first grouped into smaller clusters, variously known as biogens, biophores, micellæ, plastidules, 
etc., and then a number of these biogens unite to form the unicellular organism, or the cells of the higher animal. The biogen would be below the range of microscopic visibility. It would only come into definite view when a number clustered together to form a microbe. It is believed by several competent biologists (such as Dr. Bastian, Professor Naegeli, Professor Bölsche, Professor Haeckel, etc.) that these biogens may be forming daily in our waters, and only coming upon our horizon when a number of them have combined. Some of these students think the tiny formless specks which the microscopist often notices and ignores in his water-slide may be such biogens.

However that may be, the evolutionist must assume that something like the biogens preceded the microbe in point of time. But the biogen is still a particle of plasm, and we have not in nature any series of inorganic substances bridging the distance between plasm and ordinary matter. How does the evolutionist cover the discrepancy? He may decline the attempt and remain agnostic. Sir W. Turner dealt with the subject in his presidential address to the British Association a few years ago, and took up that attitude. It is the habitual one among biologists. They are entirely opposed to the creationist or the spiritist solutions, as altogether groundless; but at the same time they hesitate to frame a hypothesis in the present state of our knowledge. Others advance the following considerations.

It is very difficult for us to realise the condition of the earth at the time definite living things appeared, and during the long series of chemical combinations that culminated in 
the formation of plasm. The crust of the earth was very thin, and its internal heat would affect the surface to some unknown extent. Little land emerged from the vast ocean that enfolded almost the entire globe. The water of the ocean would be far hotter and denser than it is to-day. The atmosphere also would be hotter, denser, far more charged with carbonic acid, and infinitely more clouded than it is today. The forests that covered the emerging continents at a later date drew an immense amount of carbon from it. The electrical condition of such a globe is beyond our power of calculation. Further, we know to-day of the possibility of an immense amount of radio-activity that we cannot determine or reproduce. And it must be carefully borne in mind that Mr. Burke's radiobes are claimed to be the outcome of radio-action on a mixture of gelatine and beef-juice; while electricity has a mysterious but certainly important relation to life.

The candid student will realise that in this very different state of the earth chemical effects might very well be produced that are produced no longer. In the shallows of the primitive ocean, especially, there would be a vast quantity of disintegrating matter, and, in fact, diffused through the whole of the primitive ocean. It is by no means pure water to-day, as everybody knows. Compounds of carbon and water with nitrogen and other elements would not in the least be improbable. Verworn points out that these elements were probably among the first to be formed, on account of their low atomic weights. These unstable and highly absorptive compounds-they are well known to have a high 
"residual affinity," even after their primary combinationwould tend to increase in chemical complexity. It would be absurd to attempt to retrace all the steps, but the evolution of protoplasm along these lines is conceivable. But there is another conjecture to be taken into account.

A German physiologist, Pfiüger, noticed that compounds containing cyanogen had the closest resemblance to living matter. Cyanogen is a compound of carbon and nitrogen (bicarbide of nitrogen), and a peculiar feature of it is that the mere mixture of these elements never produces it ; they must be brought together at an intense heat. Pflüger at once reverted to the fact that our earth began its career in a state of incandescence. Why may not vast quantities of cyanogen, or cyanic compounds, have been produced at that time? Here would be a very plausible basis for the gradual upbuild of protoplasm. It must not be supposed that nature went steadily ahead in its manufacture. A thousand other compounds might be formed at hazard, just as thousands of animal forms have been produced that did not persist. The compounds that lay in the direction of plasm were the more stable and absorptive or reproductive. The cyanic compounds would unite easily with carbon compounds, and afterwards with water. At last a compound would be created, of which the molecules clung together in small groups. With their high power of imbibition they would grow and swell from their common centre, then split up, or detach fragments from themselves, when a convenient limit of size was reached. Metabolism would be a chemical and physical outcome of their texture (we have it "in the 
behaviour of nitric acid in the production of concentrated sulphuric acid," says Verworn); the breaking up of the group of molecules would mean an expansion beyond the slender cohering power of the group as such. The detached molecules would cling together by their individual adhesive power, and grow again by their power of imbibition. In the course of time the small cohering groups of molecules that we may call biogens would cluster together to form larger groups (still less than the five-thousandth of an inch in diameter), just as we know the cells came afterwards to cling together to form the multicellular animal. In that case we should have our first microbes. Each biogen would live its own life, as each cell does in the simpler multicellular body; but there would be an advantage in cohering -an advantage quite parallel to the cohering of social groups.

This is not a theory of the origin of life, but a provisional reply to those who profess a complete inability to conceive the natural evolution of plasm. It is speculative from beginning to end, but is entirely based on known facts. It starts from a fact, and it merely assumes that the methods we afterwards find at work in the evolution of life were, in proportionate form, at work from the first. The same methods or facts are familiar to the astronomer in cosmic development, and they are familiar to the sociologist as well as the biologist. The evolution of civilisation out of the chaos of the Neanderthal race is singularly parallel to it. The chemist finds the same struggle for life in parts of his world that the biologist does in organic nature. The 
evolution of the comparatively stable atom and of the chemical element is not more wonderful. You might as well claim a "guiding and controlling" principle in the atom of carbon, with its complex arrangement of electrons, as in the biogen or the Procytella. In each case the "soul" is the harmonious adjustment of the energies of the separate particles.

Lastly, let me emphasise the fact that modern physics has introduced a new factor that may have been very important in this creation of stable groups of molecules of plasm. mean radio-activity. Without giving positive adhesion to Mr. Burke's claims, it is most instructive to examine them. $\mathrm{He}$ and other students claim that they have turned the battery of radium particles on tubes of organic matter, and after a time living things have appeared in the carefully sterilised solutions. This would mean that under the fierce rain of electrons, or particles of electricity (or particles of ether charged with electricity), the molecules once more grouped themselves into stable clusters. Now, it is quite impossible to say what may or may not have been the extent of radio-activity in the peculiar early stages of our planet, and so we have in it a very distinct possibility of great importance.

It is along these lines that the experts who are chiefly engaged on the problem of the origin of life are proceeding. They have already formulated conjectures that dispense us from calling in the mystic aid of a creator. As Lord Kelvin insisted long ago: "If a probable solution, consistent with the ordinary course of nature, can be found, we must not invoke an act of Creative Power." With the gathering 
material for such a natural solution at hand, it would be absurd for us to say that science has exhausted its possibilities, and we must fall back on mysticism. On the contrary, we are just on the eve of great scientific constructions. Already it is clear that they will have a bearing on this profound biological problem.

It has been stated over and over again that the new discoveries in physics have "undermined Materialism." What "Materialism" is it would be difficult to say, as the writers who habitually use the word-religious writers like Sir O. Lodge-do not define it consistently. But if we are to take it that it means the view of life which resolves all things into matter and energy, the error is somewhat puzzling. Matter will probably, in the long run, be resolved into ether. That is exactly what "Materialists" have predicted for a long time. A Monist and evolutionist especially must be gratified to see the diverse chemical elements resolved into ether. Sir O. Lodge, while encouraging the loose talk about the discomfiture of the "Materialist," says that inertia is the most fundamental property of matter we know (p. 27), and that when the atom is resolved into electrons inertia will certainly "not have disappeared" (p. 29-italics his). As to energy, on which physical teaching is as yet most inconsistent, the Monist will gladly welcome an attempt to settle its close relation to "matter." And, beyond these two points, the only promise of the new radio-activity as yet is a strong suggestion that it may help us materially to explain the natural evolution of life ! 


\section{Nóte on Materialism.}

Sir Oliver Lodge insists on describing Haeckel's philosophy as Materialism. He at times alters it-if it is an alteration-to Materialistic-Monism, though he says this qualification is hardly necessary in the case of Haeckel. "Half-informed people," he says, have claimed Huxley as a Materialist, but he "was really nothing of the kind." I turn to the obituary notice of Huxley in our chief scientific journal, Nature, and find that he is there described as a Materialist. And the "half-informed " person who wrote it (unfortunately since dead) was no less a scientist than Sir W. T. Thiselton-Dyer, who professed to follow the same philosophy.

On the main point I can only say that if by a Materialist (a name that Haeckel has always expressly repudiated, though Sir Oliver never mentions that) you mean a philosopher who takes matter to be the one fundamental reality, Haeckel is not and never was a Materialist. He believes energy to be as fundamental and even more important than matter. And if the man who believes matter and energy to be the only known fundamental agencies (or aspects of some one fundamental substance) is a "Materialist," the philosophy flourishes exceedingly among men of science to-day. As Professor Ray Lankester writes, in the article on "Zoology" in the Encyclopadia Britannica: "It is the aim or business of those occupied with biology to assign living things, in all their variety of form and activity, to the 
one set of forces recognised by the physicist and the chemist." When, further, Sir Oliver Lodge airily observes that "why Haeckel chooses to regard matter and energy as one thing instead of two is not perfectly plain to me, nor, I venture to say is it really plain to him" (p. 35), we may advise him to turn to his own next page and see how he describes ether as the one persistent thing, or "the most fundamental known entity," in the material universe; or to p. I03, where he tells us that the "fundamental entities" are "ether and motion." In other words, "energy" and "matter" are identified in "ether" (motion certainly not being an entity). He would also find, on patient inquiry, that Haeckel nowhere says matter and energy are the "same thing," but are two aspects of the fundamental reality, much as the physicist does. Many physicists and chemists say (I quote Mr. Whetham) that matter is composed of energy. Ostwald, the only living physicist that Sir Oliver Lodge quotes as "perhaps" agreeing with Haeckel, really belongs to the latter school, differs entirely from Haeckel, and is explicitly repudiated by Haeckel (p. 8). Haeckel's "monism of the inorganic world " is the ordinary teaching of physical science. These things, the reader will note, are not biological matters with which Sir Oliver Lodge may be presumed to be unfamiliar.

In fine, it is most interesting to note that, if Sir O. Lodge is right in saying that physical science now admits only "ether and motion," we seem to be on the way to the prettiest revival of Materialism that one could conceive. Since the biologist will have none of Sir Oliver's immaterial 
vital power, but will reduce vital functions "to the one set of forces recognised by the physicist and chemist," it would seem that matter and motion are in a fair way to be approved as the fundamental realities. Thus we should go back to the oldest and most real type of Materialism. And this after all the aristocratic scorn we have poured on that base, plebeian philosophy! 


\section{Chapter V. \\ THE EVOLUTION OF LIFE AND MIND}

SoMEWHERE, then, in the primitive Laurentian ocean the earliest definite living things make their appearance. Unless we arbitrarily desert the elementary methods of scientific inquiry, we assume that they were the outcome of a long evolutionary process. We are able to offer several plausible conjectures, even in the present very imperfect state of our knowledge, as to the lines of this evolution. In any case, we see nothing in the simple life of these tiny microbes that forbids us to apply scientific methods to them, and compels us to resign them to the mystic. Science is "bound by the everlasting law of honour," in Lord Kelvin's words, to resist these mystic claims of invasion from an immaterial world as long as natural development is conceivable. On that principle Lord Kelvin (then Sir W. Thomson) conjectured that they may have been evolved on some other planet, and carried to ours on a meteorite. That was several decades ago. To-day we realise that our planet may very well have been the original theatre of their appearance.

The first living things were, of course, of a purely vegetal character. They had no rudiment of locomotory organs, 
no distinction of nucleus and cell-body, and they built up their plasm directly out of inorganic matter by the natural "imbibitional energy" which was a consequence of their loose texture and their large proportion of carbon and water. Animal organisms could only appear when there were already vegetal organisms to feed on. In the course of time the hereditary matter would concentrate in security at the centre of the globule of plasm; we should have nucleated cells. The mechanical strain outwards of the loose plasm towards contiguous particles of food would induce the formation of temporary folds or projections; we should have the first organs of locomotion, the first rhizopods. The mechanical strain on the surface particles would lead to the formation of a protective membrane, and the loose flow of the plasm into temporary arms or legs would have to be replaced by permanent threads or hairs or lashes (cilia), with which the water could be struck as with oars; we should have the first infusoria. Meantime, the principle of aggregation would be steadily at work, and loosely individualised clusters of cells (of which many live to-day) would be formed. Each cell would live its own life; it would be forced to the surface of the cluster, and the centre would be hollow. An intenser absorption of the food-bearing stream of water at one spot would make an indentation at that spot, and the ball would in time double upon itself (we have very strong proof in embryology that this was the next step). Thus we should have a primitive stomach and a primitive mouth. Motion through the water would lengthen the body, make it evenly bilateral, and give it a definite head and tail (as 
the evolution of the boat plainly shows). We should thus have a lowly worm-like organism. Continued motion through the water would cause folds on the back of the animal (which would shape into fins), and strengthen the central column until it became cartilage and finally bone. From the fish upward the evolution of life is intelligible enough. All the reptiles, birds, and mammals are clearly traced to a fish-ancestor.

It would be ridiculous to expect science already to furnish a complete mechanical scheme of this million-year process of development. We may leave something for our children and grandchildren to do. But it would be equally ridiculous to say that, until such a scheme is forthcoming, we can be seriously asked to consider the spiritist theory. The logical alternative to mechanism is not spiritism, but agnosticism. Spiritist theories about life have no logical status whatever unless they prove that the mechanical theory is not only temporarily, but for ever, incompetent to explain life. The Vitalist can only ask us to believe in his immaterial world when he has pointed out some feature of life that lies clearly beyond any possible extension of physical and chemical forces. We have seen that there is nothing whatever of the kind in the life of the simplest organisms. At what point are such features claimed to appear?

Unfortunately, Sir O. Lodge shrinks from assigning any definite point for us to examine. He prefers to use the word "life" "in a quite general sense" (p. 40). To view things in a quite general sense is one of the most prolific sources of fallacy known to science. If we take those 
psychic phenomena, on which Sir O. Lodge ultimately grounds his theory, in the same general way, we are likely to be debarred from ever entering upon an examination of them, as a hole-and-corner business, marked by a remarkable story of fraud and hallucination. It is always more profitable to rise from well-established details and facts to generalisations. However, Sir O. Lodge dwells so much on consciousness that we must single this out as par excellence the vital function that he believes to be immaterial. ${ }^{x}$

I am not going to attempt to give a mechanical explanation of consciousness. The only relevant thing to do is to show the complete futility of the reasons alleged by those who say it cannot be of material origin, and therefore must be from an immaterial world. The best way to approach the subject is through the evolution of mind. There are philosophical critics of Haeckel who fancy that to prove the evolution of consciousness proves nothing as to its nature. But $\mathrm{I}$ find that one of the latest German writers on philosophy, Dr. Otto Gramzow, declares that Haeckel's "criticism of Kant's philosophy from the evolutionary

"Here he has positive data on which to speak of Haeckel being " abandoned by his colleagues," or a few of them. He dwells on it with luxuriant rhetoric, but even here has to improve on the facts. $\mathrm{He}$ says the seceders from Haeckel have "marched in a more idealistic direction." Now, the chief of them was Professor Virchow, and Virchow declined to apply the mechanical theory to consciousness on the express and repeated ground that he wanted a basis for "compromise with the ruling Churches." Some of us prefer the "idealism" that makes no compromise where truth is concerned. 
point of view is the most important advance made in that science since the days of its founder" (Geschichte der Philosophie seit Kant, p. 497). This is a sensible estimate. As long as you take the fully developed consciousness of a modern man and set it crudely over against inorganic nature, it is easy to see a vast gulf between the two. But the procedure is about as scientific as that of the savage who pronounced a watch to have a soul because it was so different from any inanimate thing he had seen. When, on the other hand, we trace the mind of the European back through the series of prehistoric skulls to the ape-man of Java and the extinct ape-forms of the Tertiary period; when we see the mind of the ape sinking gradually into that of the opossum, the duck-bill, the lizard, the salamander, the mud-fish, the shark, and the ostracod, until it ends in the feeblest glimmering of psychic force, we have taken a most important step towards the explanation of the mind. Let us proceed the inverse way, and trace the upward evolution of mind, and see whether at any point there is so new and striking a departure that we must draw on an "immaterial world " to explain it.

There is a distinct psychic life in the unicellular amœbæ and radiolaria and infusoria. The amœba shrinks from an acid or from the point of a needle. The radiolarian will build up a most beautiful flinty structure to dwell in, that only a consummate sculptor could reproduce. The infusorian is very sensitive to an electric current, and differently sensitive to different currents. Is the sensitiveness of the amœba to acid or of the Paramacium to 
electricity something so mysterious that we must rush beyond nature for the explanation? When we remember the enormous chemical complexity of their texture, the high sensitiveness of much simpler compounds and of many plants, etc., it would not be very rational to do so. A beautiful radiolarian like the Lychnaspis miranda will no doubt impress the imagination of the inexpert. It must have something equivalent to memory as well as the power to create a most artistic structure, since it always builds as its progenitor did. But the whole activity of the structureless speck of jelly is undoubtedly unconscious; and we can arrange the four thousand species of radiolaria in an evolutionary series, and trace the utilitarian growth of the shell. The vegetal diatom also forms at times a wonderfully pretty shell. We have no ground to say that these feeble psychic powers are beyond the range of the intricate plexus of inorganic forces that we know to exist in the unicellular body.

When we rise to the first stages of the multicellular animal there is no material change. The aggregation is loose, and each cell retains its general sensitiveness. At last division of labour sets in. Some cells confine themselves to reproduction, some to digestion, some to locomotion, some to sensitiveness. Does the mere fact of division of labour, or the differentiation of cells for particular functions, demand the acquisition of an immaterial principle? ${ }^{x}$ And if not, there is no reason why natural

x Bear in mind, too, that such an admission would explain nothing. This applies to Sir O. Lodge's theory generally. The moment you 
selection should not increase the "irritability" of some of the cells (the future sense-cells) as well as the "imbibition" of others (the gástric cells). In both cases we merely assume a local development of known and natural properties of protoplasm. These new sense-cells would be gathered by natural selection at the head of the worm-like organism, where they are most needed. To be of service they would have to connect with the rest of the frame by means of telegraphic fibres. We should have the primitive brain and nervous system. Do we need a supernatural principle to understand this structure, and the corresponding psychic life, in such organisms?

The number and organisation of the very valuable sensitive cells would be fostered by natural selection. We

press it in detail it proves utterly useless. How does this intangible something (neither matter nor force nor energy nor substance) act on the molecules or biogens? Sir Oliver Lodge contends that "energies" may be "directed" by a principle that is not an "energy." But elsewhere (pp. 36 and 103) he abandons "energies," and leaves only etherparticles in motion in the frame of an organism, and says that material particles only move when they are "pushed from behind." How can his mystic principle, which is a "power" but not a "force," come in contact with them, and alter the direction of their movement? In all the supposed analogies that he gives (p. 170) the real guiding forces are not abstract ideas or volitions, but very concrete movements in the nerves and brain. And even if we overlook this formidable difficulty, the way in which the control is exercised would be just as unintelligible. To argue from our conscious guidance of energies to an unconscious guidance of them in lower organisms is to violate all the laws of analogy. How does this " bit" from a big "spiritual lump" tell off some cells for digestion, others for sensation, etc.? Has it a conscious plan? Does it act at a distance? We ask a hundred questions in vain. His theory is infinitely less intelligible than the most defective mechanical scheme. It is a mere flash of imagination. 
find the primitive ganglion communicating by threads with sensitive depressions in the skin of the head (the rudiments of the eyes, ears, and nose-pits) ; and we find it extending along the back (some suggest that it crept along a discarded alimentary tube). While this extension grows into the spinal cord, the important bulb at the front, the intelligencedepartment of the animal, with its advanced sentinels, the sense-pits on the face, are bound to be continuously advanced by selection. We come as far as the brain and distinct eyes of the lamprey. With such excellent material to work upon in the lower organism, and millions of years to work in, who will say that natural selection could not have produced them? And from the lowest fishes, in which the brain begins to differentiate into its five parts or vesicles, we trace a gradual growth without difficulty right up to the ape. We know to-day that intelligence is connected chiefly with the second vesicle. In the fishes and amphibians natural selection developes chiefly the third vesicle; and they exhibit a limited intelligence. In the reptiles and birds it developes the first vesicle; and there are corresponding limits to their mental development. In the mammals it developes the second vesicle, the cerebrum; and the higher mind begins to appear. In the opossum the convolutions commence, showing the growth of the cerebral matter. They increase in complexity right up to the orang. The psychic life advances in exactly the same proportion. Which is the more rational and scientific: to say that this advancing intelligence is the function of the brain, improving as the organ improves, or to say that at some point or other 
the natural function of the brain disappears, and all its wonderfully intricate structure is only a means of letting in some visitant from another world?

But man does not descend from the anthropoid ape, and, if he did, we should still have to recognise a great mental distance between the two. Anthropologists are almost unanimous to-day in saying that man descends from an extinct lemur or ape-like form of the Tertiary period. We find skulls of such in France and elsewhere. The next chief stage is believed to have been similar to that of the gibbon. But the lowest savage brains to-day are immensely superior to the anthropoid ape. Have we a chance of interpolating our visitant from another world somewhere between the apestage and the human? We have not the least chance of it. We have discovered an intermediate form between the ape and man (the pithecanthropus of Java, now generally admitted), with a low simian skull (just half way in cranial capacity between the orang and the lowest human skull), simian teeth, and curved thigh-bones. We have half-a-dozen accredited skulls or jaws of the first race of prehistoric men (Neanderthal, Spy, Krapina, Schipka, La Naulette, and Arcy, with other probable ones), and they tell absolutely of gradual development. The Neanderthal-Spy man had a low forehead, prominent eye-ridges, powerful receding jaws, no faculty of articulate speech, curved thighs, and a short, hairy, muscular frame. The implements he has left tell exactly the same story of gradual mental development. The whole science of prehistoric man, starting at what Sir J. Evans (a conservative expert) calls an "immensely remote epoch," is 
a consistent proof of the gradual advance of intelligence. From the amœba to man there is no startling break that would justify us in deserting natural agencies.

We began with the gathering of a few sensitive cells in the fore part of a lowly worm. We end with a brain of inconceivable complexity. The sensitive cell in the lower organism differs little from the others : the ganglionic cell in the human brain is a microcosm in itself. It is one of the largest cells in the body, has a structure of astonishing intricacy, and is connected with its neighbours by an elaborate network of fibrils. Millions upon millions of these cells are woven into the gray bed or cortex of the brain, with which intelligence is associated. To say that all this complexity is only for the purpose of letting in a spiritual principle from another world is gratuitous in the extreme. It is more scientific to suppose that the sensitive cells and their function have advanced in a normal and natural fashion.

Sir O. Lodge nowhere alludes to this vast and significant array of facts that seem to point to consciousness as a function of the brain. He prefers to dub it "Materialism," and quote Huxley as a warning to "would-be Materialists"; while he makes it perfectly clear in other parts (such as p. 75 and p. ro8) that he does not himself accept those idealist principles which lie at the root of Huxley's strictures, and which are accepted by few men of science to-day. Later, however, he offers us a few considerations which purport to convince us that mind may, after all this evolution (of which he says nothing), not be a function of the brain at all. These are mostly in the form of analogies. 
84

The first is the analogy of the eye as " the organ of vision." $\mathrm{He}$ labours to show that light would remain whether the eye were destroyed or not. I pointed out to him in the Hibbert that light is not the function of the eye, and so there is not the remotest parallel. When he can tell us of a case where vision has remained when the eye was destroyed, there will be a pertinent and instructive analogy; or when he finds Haeckel, or some more foolish person, saying that when the brain is destroyed the things that stimulated it also cease to exist. He seems to think this curious fallacy is mended by adding that, in the event of our eyes ceasing to act, " a term like 'vision' might still be employed to signify our mode of perceiving and experiencing the agency which now manifests itself to our eyes" (p. I Io). It certainly might, but-"vision" would then be a function of a different material organ altogether. The function of the eye would not have persisted at all as a disembodied something, and so again there is not the remotest analogy to his theory of the survival of the disembodied mind. Sir O. Lodge's expertness in revising the terms of Christian theology seems to have its disadvantages.

His second analogy is a slightly new variation on that worn musical metaphor of brain being the "organ" of the mind. The old, familiar version was that the soul was the musician. Sir Oliver Lodge puts it that the organ is "an instrument for the incarnation of music." $\mathrm{He}$ asks us to believe that music-say "the ideas of Sir Edward Elgar"would still exist if all the organs in the world were destroyed. This is a strange confusion of three totally different things, to 
which we give the same name by metaphor. There is music as a harmony of acoustic sensations, music as a series of aerial waves, and music as a conception in the artist's mind. The organ of each is totally different, and it is mere conjuring to point out that the musician's ideas remain (in his brain, remember, not disembodied, as far as experience goes) when the organ of musical sounds has been destroyed. Incidentally, Sir Oliver Lodge speaks with respect of the medieval idea that the cosmic system might be the "brain of some transcendent Mind" (p. II2). He goes on to speak of this as "a lofty kind of pantheism," beside which "the miserable degraded monism" of Haeckel is "not likely to survive as a system of perennial truth." In this case I need only state his position.

The third analogy is equally unfortunate. The writing or the speaking of a sentence is "an incarnation of its meaning." Sentences may perish, but the meaning "may exist as an eternal 'now.'" A medieval theologian would subscribe to that. A modern critic would probably point out that "incarnation" is a pure metaphor, and that the meaning of the sentence cannot exist except in a living mind and, as far as experience goes, brain.

$\mathrm{He}$ concludes this series of arguments with the remark that philosophers like Haeckel "must be content with an audience of uneducated persons," and must be prepared to meet "other men of science" who "perceive possibilities to which the said narrow and over-definite philosophers are blind."

He then plunges into a sea of metaphors where one can 
but distantly follow his bold swimming. "I would not too blatantly assert that even a doll on which much affection had been lavished was wholly inert and material in the inorganic sense." "I have reason to believe that a trace of individuality can cling about terrestrial objects in a vague and almost inperceptible fashion, but to a degree sufficient to enable those traces to be detected by persons with suitable faculties" (p. I 22). Here we get just a momentary glimpse of the real foundations of his philosophy; all the rest are false buttresses. Parliament and the Army are offered us as analogues of "entities" that may exist disembodied, when their constituent elements are dissolved. Magnetism is finely developed as an analogy to life (most "Materialists" will sympathise with that) until the critical point is reached, when-just as we are beginning to wonder what the precise analogy is to an "immaterial ". principleit is discarded as "useful no longer." But when he adds that if one conceived magnetism as "brought into relation with the world of matter by certain acts," controlling it for a time, and then "disappearing to the immaterial region whence it came" - when he says this "no physicist would think it worth while to object to, and many indeed might agree with," we are moved with pity for the "uneducated reader." Sir O. Lodge has already assured us that ether is matter (p. 29), and has discarded the idea of separate inorganic energy in the name of "physical science" (p. I03).

For such considerations we are asked to resist the natural 
scientific inference from the parallelism of mind and brain, and think the brain is merely an elaborate grand piano on which a ghostly visitant plays mysterious music. It is a strange issue for a man of science who holds that a very complex grouping of atoms "is likely to have properties differing not only in degree but in kind from the properties of simple substances" (p. I86). When we do offer him a grouping of atoms of the most inconceivable complexitythe human brain-he will not even allow that it has developed properties differing in degree from those of the lowly animal ganglion. Its energies have had to be overruled by an intangible something from another world, which forbids science ever, to hope to analyse consciousness-in this world. In the old unscientific way, life and mind are set aside with the mysterious label, "spirit," on them, and the biologist and psychologist are told that their central objects of interest lie in a hazy world to which they have no possible access until their brains-their organs of thought and reason-are paralysed by death. One must judge leniently the hard language in which they have characterised these airy speculations of our distinguished physicist.

Sir Oliver Lodge might reply that it is the place of the biologist to deal with the phenomena of life, and of the psychologist to describe and classify the phenomena of mind; that they are not concerned with the substance or essence of either. It must be confessed that many men of science have expressed their function in these terms, and so provided some ground for the distinction. On such a theory it could very plausibly be contended that while a 
Professor Ray-Lankester retained a commanding authority on the phenomena of life, or a Professor Sully on the phenomena of mind, it was still open for a thinker, who was expert in neither branch of science, seriously to oppose them in regard to the essence of life and mind. The language which still lingers in certain schools of metaphysics encourages the idea, and the influence of Hume on English science has been almost equally mischievous. Professor Karl Pearson's Grammar of Science still supports the distinction, and a quite recent and competent writer on physics, Mr. Whetham, repeats confidently that the science deals only with the "phenomena" of matter, and reaches the outrageous conclusion that the ultimate form of matter is " immaterial," the ultimate ground of nature "supernatural."

In his important address to the British Association in I90 Sir Arthur Rücker, one of our ablest physicists, made it perfectly clear that this is a false conception of scientific work. He claimed, in the name of physics, that his science dealt with objective realities when it spoke of "atoms" and "ether," and was giving us real and minute information about them. Few scientific men now imagine that the "essences" of things are shrouded from our gaze by a surrounding veil of "phenomena"; or that, as Plato taught 2,000 years ago, our senses perceive the outer shell of phenomena, and our intuitive and purely spiritual faculties pierce to the kernel or "essence." All this is getting antiquated. "Phenomenon" means "appearing." We are slowly but surely recognising that to talk of "appearances" divorced from "realities" is nonsense. It is the realities 
that "appear" to us, or are sensed by us. That is the literal and the only intelligible meaning of the term " phenomena," which has been so useful to the theologian in his modern conflict with science. Odour, pressure, colour, etc. (I am not, of course, speaking of the sensations these produce in us), are not a mysterious metaphysical peel of the "real" orange. They are the matter of the orange shooting at our olfactory nerve, reflecting the ethereal waves to our retina, and so forth.

It is the same with biology and psychology. It has been very convenient for certain reactionary schools of thought to assume that the "phenomena" of life and mind are something separate from the realities. The naturalist could then be left to deal with the former, while the supernaturalist still extended his mystic theories to the latter. The distinction is a mere survival of the older superficial way of looking at things. Modern science knows nothing of "qualities" so distinct from objects that-as the Catholic believes to be the case in the Mass - the substance (of the bread or wine) can be annihilated and the qualities remain intact. This is a childish conception in science to-day. Life and mind, in the concrete, have no qualities or phenomena distinct from themselves, in the sense that biology and psychology can deal extensively with the former, yet leave the latter under the veil. Such a work as Haeckel's Wonders of Life tells you a vast amount about life, not about the phenomena of life (in the distinct sense). Such a work as Sully's Psychology gives you a mass of information about the mind itself. 
Thus Sir Oliver Lodge comes into direct conflict with our biologists and psychologists. They may not think their research is as yet complete enough to justify them in defining life and mind as mechanical, but they are not at all willing to see those realities airily thrust into a spectral world beyond their reach. What, indeed, would the average reader, who has no system to defend, gain by the adoption of Sir Oliver Lodge's desperate resource? Nothing whatever. He may find Haeckel's theories of life and mind inadequate, but assuredly he will get little intellectual satisfaction in admitting that they are "spirit." What is "spirit"? No spiritist will give you any consistent definition. In earlier days there was a very clear distinction drawn between matter and spirit. Matter was extended or quantitative substance-substance occupying space; spirit was substance without parts or spatial extension. Sir Oliver Lodge ridicules this old antithesis (p. r29, where a knowledge of the historical distinction would again have spared him the strain on his courtesy), but nowhere suggests a better. He says that the fundamental property of matter is inertia. The "immaterial," which is the essence of his theory, he nowhere attempts to define. If it is to be something devoid of even the quality of inertia, it becomes totally unthinkable - a far more profound enigma than any of those biological difficulties which it is brought in to unravel. In one place Sir Oliver Lodge seems to look to "ether" for an intelligible idea of spirit (p. I I I), as many spiritists do. But he has elsewhere explained that ether retains inertia, and that therefore to speak of it as immaterial 
(as Mr. Whetham does) is absurd. We are thus left without the slenderest definition of what spirit is. It is the mere shadow of an ancient name.

And this is only one of the difficulties that beset Sir Oliver Lodge's theory the moment you examine it closely. A hundred difficulties arise as to the manner in which this immaterial entity acts on the matter of the animal's frame. If it be true that, as he says, modern physics sees only ether-particles in motion in the universe, the question how the immaterial can act on the ether-particles and "direct" their movements is a serious one. Against his biological critics he makes, or tries to make, one point of importance in the name of physics :-

My contention is-and in this contention I am practically speaking for my brother physicists-that whereas life or mind can neither generate energy nor directly exert force, yet it can cause matter to exert force on matter, and so can exercise guidance and control : it can so prepare any scene of activity, by arranging the position of existing material, and timing the liberation of existing energy, as to produce results concordant with an idea or scheme or intention (p. 164).

Now, if in this vague statement Sir Oliver Lodge is making a claim for "life or mind" that is not admitted by the biologists he sets out to attack, he has no warrant whatever for speaking in the name of his "brother physicists." His words are more misleading for the "uncultured reader," for whom he is so concerned, than any that Haeckel has penned. One or two physicists-like Lord Kelvin or Sir W. Crookes-might agree with him, but they 
would not do so on physical grounds, and more of his "brother physicists" would emphatically dissent (such as Sir A. Rücker and Sir J. Dewar and others). It is not a concern of physics at all.

If, on the other hand, we do not press too hard the vague closing words of the passage I have quoted, not only physicists, but Haeckel and others, will admit it. This is clear from the instances given, such as guiding a falling rock so as to fire a detonator, guiding a pen so as to produce intelligible characters, or pulling a hair-trigger or opening the throttle-valve of an engine. Certainly here we have guidance of energies with a definite purpose. But, as in the case of most of Sir Oliver Lodge's "analogues," there is no real analogy at all. In each case, he admits, a nerveprocess initiates the action, and this in turn is originated by "some chemical process." He suggests that the latter was set going by some immaterial power called will. This is wholly gratuitous, and wholly unintelligible. Modern psychology sees no spiritual initiation of volitions at all. There is a constant current of ganglionic processes pouring through the brain from the nerves that communicate with the outer world, and these shape the desires or plans or volitions. At all events, Sir Oliver Lodge is begging the whole question when he assumes an immaterial startingpoint. We know only nerve-processes, with the psychic reflection of them in consciousness. Sir Oliver Lodge can give us no instance whatever of the guidance of inorganic matter or energy by something that is clearly not material.

Thus the difficulty remains in full force. To "guide" 
material energies means to move material particles. Of disembodied energies we know nothing-I have shown how Sir Oliver Lodge discards "energy" altogether when he is asked for the fundamental factors in physics, and recognises only moving particles of ether. How does the immaterial move particles of matter? And when this difficulty is fully realised, another awaits us. To build up the frame of a single organism and direct its energies for the common lifepurposes, his immaterial principle would have to be as conscious, as deliberate, as much guided by a plan, as the man who puts the stones together to form a house. Who will admit this for the lower type of animals or for the plants? From every point of view, it is far more satisfactory to look to the unconscious, elaborate mechanism of the organism, which science is gradually mastering.

How comes it that a man like Sir Oliver Lodge so clearly deserts ordinary scientific procedure in his speculations on life, and makes these desperate efforts to introduce the immaterial ? His position can only be understood when we remember that he is convinced of the immateriality of mind from a totally different set of considerations-from psychical research. As these considerations are not mentioned in his book, I cannot deal with them. It is, however, only just to him to point out that the arguments I have analysed-the analogies and speculations and conjectures that crumble into dust the moment you seriously test themare not the real grounds of his conviction. I will only say that those real grounds have nothing to do with his competence as a man of science, and that they only bring him 
to a point which is, comparatively, not much nearer to orthodox theology than is the position of Professor Haeckel. The Churches of our time have reeled under the blows of men of science like Darwin, Huxley, Tyndall, Spencer, Clifford, Maudsley, and Haeckel. Apart from the more scholarly and liberal divines, the Churches still expose themselves to the force of those blows. The mass of believers are kept in ignorance of the real opinions of their own most learned divines, and the official teaching of all the Churches is such as not a single eminent scholar in Europe (apart from the clergy) can endorse to-day. In face of these attacks the Churches look in vain for allies among men of science. It is a profound mistake to imagine that Sir Oliver Lodge is presenting himself as a champion of the creeds against Professor Haeckel.

What is his final position on the familiar religious issues? It is true that he tells us "a soul is always immortal where a soul can be discerned" (p. II6), and he speaks of a "transcendent mind" and the "Sustainer and Comprehender" of the universe, though why the universe needs a "Sustainer" when Sir Oliver thinks anything "which really and fundamentally exists......can be trusted not suddenly to go out of existence," is not clear. As the point is interesting, and as Sir Oliver Lodge is widely claimed as a supporter of our Churches, I close with a few observations on his theological position. I find them fairly clearly expressed in an address on Science and Religion that he delivered at the City Temple (November and, 1905), and has since published. 
Sir Oliver Lodge believes in God, but not in a Father "Almighty," nor in a "Creator of heaven and earth." "The struggle and effort towards progress......ertends even to the Deity" (p. 5) ; "I do not believe in things jumping into existence and jumping out of existence" (p. 4); "What may be the conditions of an Infinite Being we can never tell" (p. 8). Is God distinct from nature? At one point (p. 3) he begins to deny it, and then dramatically breaks his sentence; later he says : "Nature, man, God, all in a sense one." He claims constantly to be a Monist, but thinks there may be a number of totally distinct fundamental entities. $\mathrm{He}$ also thinks that "it is scientific," though "it may not be entirely philosophical," to accept a thing "although you may not be able to reconcile it fully with some other things which also you may hold to" (p. 8). He does not seem to think that God is a "pure spirit," since he suggests that the cosmic bodies may make up his brain. These are the ideas about the Deity which Christian believers fondly imagine coincide with their own.

His views of the human "soul" are not less profoundly heretical and interesting. His basic principle is "the persistence of being." If he took this as a purely empirical principle, it would help him very little towards a belief in the survival of the soul. He therefore-naïvely ignoring his unmerited stricture on Haeckel-gives it an axiomatic and self-evident character. Life is an ultimate entity, and must persist. Does that mean that the soul of the beetle or the cat survives, as well as the human soul ? The awkward conclusion is met by the framing of a fresh axiomatic 
UC SOUTHERN REGIONAL LIBRAAY FACILITY

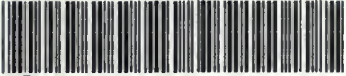

A $000757793 \quad 5$
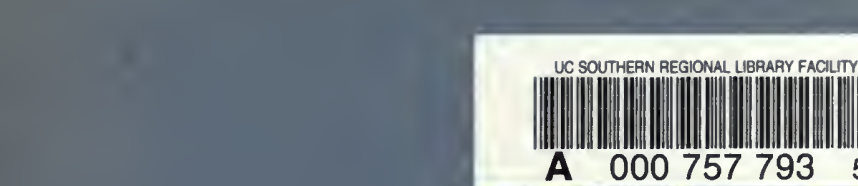
5 
